\title{
WYBORY I REFERENDUM OGÓLNOKRAJOWE NA POLSKICH STATKACH MORSKICH. FAKTY, WNIOSKI, SPOSTRZEŻENIA
}

1. Morskie prawo wyborcze leży na marginesie zarówno prawa wyborczego, jak i prawa morskiego. Jeśli jednak konstytucjonaliści poświęcają mu choć trochę uwagi (zwłaszcza rozważając powszechność prawa wyborczego i jej ograniczenia), maryniści temat ten podejmują niezwykle rzadko. Dość wspomnieć, że powszechnie znany podręcznik morskiego prawa publicznego [Koziński 2010] kwestię tę najzupełniej pomija. Ot, paradoks, zważywszy na znaczenie symboliki nautycznej dla procesu kreowania elekcyjnych organów państwa (sterowanie nawą państwową) [Chojecka 1995: 107].

Jeśli sześćdziesiąt kilka lat to w polskich warunkach już tradycja, można z należną powagą stwierdzić, że wybory odbywane na polskich statkach morskich to instytucja tradycyjna. Ustanowiono je początkowo tylko dla wyborów do rad narodowych - w art. 19 ust. 1 pkt 5 ustawy z 25 września 1954 roku - Ordynacja wyborcza do rad narodowych ${ }^{1}$, następnie otwierając możliwość ich tworzenia w wyborach do sejmu - w art. 13 pkt 4 ustawy z 24 października 1956 roku - Ordynacja wyborcza do Sejmu Polskiej Rzeczypospolitej Ludowej². Obwody głosowania na statkach nie pojawiły się w ustawie z 13 lutego 1984 roku - Ordynacja wyborcza do rad narodowych ${ }^{3}$, do organów państwa wybieranych również na morzu dołączyły jednak wkrótce senat - na podstawie art. 1 ust. 1-2 ustawy z 7 kwietnia 1989 roku - Ordynacja wyborcza do Senatu Polskiej Rzeczypospolitej Ludowej ${ }^{4}$ i art. 18 ustawy z 7 kwietnia 1989 roku - Ordynacja wyborcza

* Dr, Katedra Nauk Prawnych i Bezpieczeństwa Wewnętrznego, Wyższa Szkoła Zarządzania Ochroną Pracy w Katowicach, m.kijowski@poczta.onet.pl

${ }^{1}$ Dz. U. 1954, nr 43, poz. 193.

2 Dz. U. 1960, nr 58, poz. 325 ze zm.

3 Dz. U. 1988, nr 7, poz. 55.

${ }^{4}$ Dz. U. 1989, nr 19, poz. 103. 
do Sejmu Polskiej Rzeczypospolitej Ludowej X kadencji, na lata 1989-19935 oraz prezydent - na podstawie art. 23 ust. 3 Ustawy z 27 września 1990 roku o wyborze prezydenta Rzeczypospolitej Polskiej ${ }^{6}$. Dla wyborów na statkach nie starczyło miejsca w ustawach z 10 maja 1991 roku - Ordynacja wyborcza do Senatu Rzeczypospolitej Polskiej i z 28 czerwca 1991 roku - Ordynacja wyborcza do Sejmu Rzeczypospolitej Polskiej ${ }^{8}$, powróciły jednak przed kolejnymi wyborami parlamentarnymi na mocy art. 51 ust. 2 ustawy z 28 maja 1993 roku - Ordynacja wyborcza do Sejmu Rzeczypospolitej Polskiej. ${ }^{9}$. Ostatnim chronologicznie podmiotem, którego skład kreowany jest do dziś na statkach, jest Parlament Europejski, a stało się to na mocy art. 42 ust. 1 pkt 5 i art. 43 ust. 4 ustawy z 23 stycznia 2004 roku - Ordynacja wyborcza do Parlamentu Europejskiego ${ }^{10}$.

Niniejszy tekst odnosi się do aktualnych regulacji wyborów i referendum ogólnokrajowego w obwodach głosowania utworzonych na polskich statkach morskich na gruncie kodeksu wyborczego i ustawy z 14 marca 2003 roku o referendum ogólnokrajowym ${ }^{11}$, zaś punktem odniesienia do rozważań o praktycznym charakterze jest przede wszystkim rok 2015, w którym to (również na statkach) odbywały się wybory parlamentarne, wybory prezydenckie i referendum ogólnokrajowe. Także $\mathrm{w}$ ich kontekście podzielam zdanie kapitana żeglugi wielkiej Mirosława Folty, który stwierdził: „Niestety nie mamy biało-czerwonej bandery i nasza wspaniała komisja wyborcza nie akceptuje tego, że statki są pod inną banderą i wyborów nie przeprowadza się na statkach"12. Zarzut postawiony przez kapitana, choć nietrafnie skierowany pod adresem „wspaniałej” Państwowej Komisji Wyborczej i pomijający prawa pasażerów (im też zdarza się głosować!), jest słuszny. Niestety.

2. Ograniczenia praw jednostki na statku morskim dotyczą zakresu korzystania z czynnego prawa wyborczego. Wedle art. 15 Kodeksu wyborczego (dalej $\mathrm{kw}$ ) w celu przeprowadzenia wyborów prezydenta, wyborów do sejmu i senatu ${ }^{13}$ oraz wyborów do Parlamentu Europejskiego tworzy się obwody głosowania dla wyborców przebywających na polskich statkach morskich ${ }^{14}$

${ }_{5}^{5}$ Dz. U. 1989, nr 19, poz. 102 ze zm.

${ }^{6}$ Dz. U. 2010, nr 72, poz. 467 ze zm.

7 Dz. U. 1994, nr 54, poz. 224 ze zm.

${ }^{8}$ Dz. U. 1991, nr 59, poz. 252.

${ }^{9}$ Dz. U. 1993, nr 45, poz. 205 ze zm.

${ }^{10}$ Dz. U. 2004, nr 25, poz. 219 ze zm.

${ }_{11}$ Dz. U. 2015, poz. 318.

12 wpolityce.pl/polityka/243941-marynarze-bez-prawa-do-glosowania-wybory-mozliwe-tylko-na-statkach-z-polska-bandera.

${ }_{13} \mathrm{Z}$ wyjątkiem wyborów uzupełniających do senatu (art. $283 \S 4$ kw.).

${ }^{14}$ Zachowuje aktualność dokonana przez K. Skotnickiego [2007: 157] klasyfikacja tych obwodów głosowania do kategorii obwodów odrębnych, zwanych również specjalnymi bądź zamkniętymi. 
znajdujących się w podróży w okresie obejmującym dzień wyborów, jeśli przebywa na nich minimum 15 wyborców i jeśli możliwe jest przekazanie właściwej komisji wyborczej wyników głosowania niezwłocznie po jego zakończeniu (§ 1). Obwody te, wchodzące w skład okręgu wyborczego właściwego dla dzielnicy Śródmieście miasta stołecznego Warszawy (§ 4), tworzy minister właściwy do spraw gospodarki morskiej po zasięgnięciu opinii Państwowej Komisji Wyborczej, na wniosek kapitana statku złożony najpóźniej w 30. dniu przed dniem wyborów (§ 3), po czym - a stanowi o tym art. $16 \S 4$ - kapitan niezwłocznie zawiadamia wyborców o utworzeniu takiego obwodu. W świetle art. 6 ustawy z 14 marca 2003 roku obwody głosowania dla obywateli polskich przebywających na polskich statkach morskich tworzy się również w celu przeprowadzenia głosowania w takowym referendum (ust. 1 pkt 5) a do obwodów tych stosuje się odpowiednio przepisy kodeksu wyborczego (ust. 3) ${ }^{15}$. Kluczowe w kontekście wyborów i referendum znaczenie ma pojęcie polskiego statku morskiego zdefiniowane w art. $15 \S 2 \mathrm{kw} \mathrm{w} \mathrm{mocno}$ zawężający sposób, powiada on bowiem, że pojęciu temu odpowiada jedynie statek podnoszący polską banderę i dowodzony przez polskiego kapitana. Definicja ta znacznie odbiega zarówno od przytoczonej w art. 5 i art. 115 $\S 15$ Kodeksu karnego (dalej kk) kategorii „[polskiego] statku wodnego”, od niefortunnego „okrętu” z art. 16 ustawy z 31 stycznia 1959 roku o cmentarzach i chowaniu zmarłych ${ }^{16}$, jak i od zawartego w Kodeksie morskim (dalej km) określenia „statek o polskiej przynależności”, który ma prawo uprawiać polską banderę (art. $9 \S 1$ ) i jest zobowiązany ją podnosić (art. $11 \S 1)^{17}$ : częściowo się one pokrywają, po części zaś są od siebie wzajem mocno odległe. „Polski statek morski” z art. $15 \S 2 \mathrm{kw}$ to pojęcie węższe od zawartych w $\mathrm{Ko}$ deksie cywilnym (dalej kc) ,polskiego statku morskiego" z art. 953 (tu brak wymogu polskiego obywatelstwa kapitana) oraz „statku lub okrętu” z art. 30 $\S 1-2$.

${ }^{15}$ Art. 6 ust. 7 tej ustawy zobowiązuje też kapitana do powiadomienia osób uprawnionych do udziału w referendum o utworzeniu obwodu na statku, w odróżnieniu od Kodeksu wyborczego nie nakazuje mu jednak uczynienia tego niezwłocznie.

16 Dz. U. 2015, poz. 2126 ze zm.

${ }^{17} \mathrm{Na}$ pojęcie statku o polskiej przynależności składają się jednostki wyszczególnione w art. $10 \S 1 \mathrm{~km}$ : statek stanowiący polską własność (pkt 1), statek uważany za stanowiący polską własność (pkt 2), statek niestanowiący tejże, który uzyskał polską przynależność zgodnie z rozporządzeniem $\mathrm{nr}$ 613/91 (EWG) z 4 marca $1991 \mathrm{r}$. w sprawie transferu statków z jednego rejestru do drugiego wewnątrz Wspólnoty (pkt 2a) oraz statek niestanowiący polskiej własności, który czasowo uzyskał polską przynależność (pkt 3). Jak wspomniano wyżej, wszystkie te statki mają prawo i obowiązek podnoszenia polskiej bandery, nie są zaś one zobligowane do podróżowania pod dowództwem polskiego kapitana. 
3. W myśl art. 34 kw kapitan statku sporządza spis wyborców ${ }^{18}$, do którego wpisywani są wszyscy wyborcy przebywający na statku znajdującym się w podróży w dniu wyborów (§ 1). Wpisu dokonuje się nie z urzędu lecz na wniosek wyborcy złożony najpóźniej w trzecim dniu przed dniem wyborów; wniosek ten powinien zawierać imię (imiona) i nazwisko, imię ojca, datę urodzenia, adres zamieszkania oraz numer ewidencyjny PESEL lub numer ważnego polskiego paszportu, a w przypadku niebędących obywatelami polskimi obywateli UE - numer innego ważnego dokumentu tożsamości oraz miejsce i datę jego wydania (§ 2). Spis wyborców jest na statku udostępniany do wglądu, obowiązkiem kapitana jest zaś powiadomienie wyborców w sposób zwyczajowo przyjęty o sporządzeniu spisu oraz miejscu i czasie jego udostępniania (art. 36 § 2-4). Każdy może wnieść do kapitana statku reklamację w sprawie nieprawidłowości sporządzenia spisu; kapitan rozpatruje reklamację niezwłocznie, a od wydanej przezeń decyzji w tej sprawie nie przysługuje środek prawny (art. 37 §1-3). Raczej teoretyczne zastosowanie ma sytuacja opisana w art. $32 \S 1$ i art. 34 § 3 : otóż, jeśli wyborca zmienia miejsce pobytu przed dniem wyborów (innymi słowy schodzi na ląd, dokonuje wyokrętowania), otrzymuje na wniosek zgłoszony pisemnie, telefaksem lub w formie elektronicznej (dlaczego nie osobiście, nie ustnie?) wydane przez kapitana statku zaświadczenie o prawie głosowania w miejscu pobytu w dniu wyborów, przy czym, jeśli wniosek został przedłożony kapitanowi przed sporządzeniem przezeń spisu wyborców, zaświadczenie wydaje się na podstawie rejestru wyborców, a jeśli po sporządzeniu spisu wyborców - na podstawie tego spisu. W świetle $\S 2$ ust. 1 oraz $\S 4$ ust. 1-2 rozporządzenia Ministra Infrastruktury z 30 kwietnia 2003 roku w sprawie sposobu sporządzania i aktualizacji spisu osób uprawnionych do udziału w referendum ogólnokrajowym dla obwodów głosowania utworzonych na polskich statkach morskich $^{19}$, a także $\S 2$ ust. 2 oraz $\S 3$ ust. 1-2 rozporządzenia Ministra Infrastruktury i Rozwoju z 21 kwietnia 2015 roku w sprawie spisu wyborców dla obwodów głosowania utworzonych na polskich statkach morskich ${ }^{20}$ spis takowy sporządza się w dwóch egzemplarzach - dwustronnie, pismem maszynowym lub w formie wydruku komputerowego, albo pismem ręcznym: atramentem lub długopisem ${ }^{21}$. $§ 4$ pierwszego rozporządzenia i $\S 5$ drugiego obligują kapi-

18 Analogicznie sporządza on spis osób uprawnionych do udziału w referendum (art. 9 ust. 2 ustawy z 14 marca 2003 r.).

19 Dz. U. 2003, nr 74, poz. 669 ze zm.

${ }^{20}$ Dz. U. 2015, poz. 586.

${ }^{21} \S 5$ rozporządzenia z 30 kwietnia 2003 r. zobowiązuje kapitana statku do podpisania każdego arkusza spisu i opatrzenia go swoją pieczęcią, natomiast $\S 6$ rozporządzenia z 21 kwietnia 2015 r. - do podpisania formularza spisu imieniem i nazwiskiem oraz parafowania każdej jego strony. § 2 drugiego rozporządzenia stanowi o strukturze spisu wyborców, składającego się z części A - w wyborach do sejmu i senatu oraz prezydenckich oraz części A i B - w wyborach 
tana do powiadomienia, za pośrednictwem armatora, urzędu gminy właściwego ze względu na miejsce zamieszkania wyborcy (osoby uprawnionej do udziału w referendum) o wpisaniu go/jej do spisu lub skreśleniu z tegoż. Jeżeli wyborca (osoba uprawniona jw.) zmienia miejsce pobytu przed dniem wyborów (referendum), na jego/jej żądanie kapitan wydaje zaświadczenie o prawie do głosowania (§ 6 ust. 1 pierwszego rozporządzenia i $\S 7$ ust. 1 drugiego ${ }^{22}$ ). Spis aktualizowany jest do dnia przekazania go przez kapitana przewodniczącemu komisji obwodowej, po sporządzeniu spisu, a przed dniem głosowania, na dodatkowym arkuszu/formularzu wpisuje się bowiem osoby pominięte w spisie (jeśli reklamacja została uwzględniona przez kapitana bądź jeśli pominięto je w wyniku oczywistego błędu), ze spisu skreśla się zaś osoby, wobec których kapitan wydał decyzję o ich skreśleniu ze spisu, umieszczone w nim w wyniku oczywistego błędu oraz te, którym wydano zaświadczenie o prawie do głosowania (§ 7-8 pierwszego rozporządzenia, § 8-10 drugiego).

4. Załączniki do uchwał PKW z 24 marca 2014 roku w sprawie wytycznych dla obwodowych komisji wyborczych, dotyczących zadań i trybu przygotowania oraz przeprowadzenia głosowania $\mathrm{w}$ obwodach głosowania utworzonych za granicą i na polskich statkach morskich w wyborach do Parlamentu Europejskiego, zarządzonych na dzień 25 maja $2014 \mathrm{roku}^{23}$, z 27 lipca 2015 roku w sprawie wytycznych dla obwodowych komisji do spraw referendum, dotyczących zadań i trybu przygotowania oraz przeprowadzenia głosowania w obwodach głosowania utworzonych za granicą i na polskich statkach morskich w referendum ogólnokrajowym zarządzonym na dzień 6 września $2015 \mathrm{roku}^{24}$ oraz z 20 października 2015 roku w sprawie wytycznych dla obwodowych komisji wyborczych dotyczących zadań i trybu przygotowania oraz przeprowadzenia głosowania w obwodach głosowania utworzonych za granicą

do PE (ust. 3), przy czym część A obejmuje wyborców będących obywatelami polskimi (ust. 4), część B - wyborców będących obywatelami UE lecz nie obywatelami RP, ale wpisanych do rejestru wyborców w gminach położonych na terytorium RP (ust. 5): rzecz jasna, części B nie sporządza się na statku, na którym nie przebywają obywatele UE niebędący obywatelami RP (ust. 6).

$22 \S 7$ rozporządzenia z 21 kwietnia $2015 \mathrm{r}$. zobowiązuje ponadto kapitana do opatrzenia tego zaświadczenia numerem, podpisem i pieczęcią kapitana statku, tudzież wpisania go do ewidencji wydanych zaświadczeń o prawie do głosowania (ust. 1). W myśl ust. 5 i 9 kapitan prowadzi taką ewidencję w formie papierowej lub w systemie informatycznym. Ponadto w wyborach prezydenckich na żądanie wyborcy zmieniającego miejsce pobytu przed dniem wyborów kapitan wyda mu 2 zaświadczenia o prawie do głosowania w dniu kolejno pierwszego i ponownego głosowania (ust. 2), gdyby zaś wyborca zmieniał miejsce pobytu po pierwszej a przed drugą turą, otrzyma na swoje żądanie zaświadczenie o prawie do głosowania z oznaczeniem prawa do głosowania w dniu drugiej tury (ust. 3). Pod pojęciem rozporządzenia z 21 kwietnia 2015 r. rozumiem akt wskazany powyżej, nie zaś ten, do którego odwołuję się w przyp. 70-73.

${ }^{23}$ M. P. 2014, poz. 257.

${ }^{24}$ M. P. 2015, poz. 749. 
i na polskich statkach morskich w wyborach do Sejmu Rzeczypospolitej Polskiej i do Senatu Rzeczypospolitej Polskiej, zarządzonych na dzień 25 października $2015 \mathrm{roku}^{25}$, stanowią wytyczne zapowiedziane $\mathrm{w}$ tytułach tych uchwał. Jako że z tytułów wynika, iż uchwały te (wraz z załącznikami) zostały jednorazowo skonsumowane, nie widzę potrzeby szczegółowego omawiania wytycznych dla komisji - także dlatego, że przed wyborami i referendami odbywanymi w przyszłości będą one konstruowane zapewne w inny sposób. Istnieje jednak bezsprzecznie istotna część i uchwał i wytycznych, nie zasługująca na to, by ją pominąć. $§ 2$ każdej z trzech uchwał stanowi o odpowiednim stosowaniu załączonych wytycznych w obwodach głosowania utworzonych na polskich statkach morskich, z pewnymi jednak zastrzeżeniami (,z tym że”). Istotne, acz zawarte w jedynie w pierwszej i drugiej uchwale (§2 pkt 1) PKW jest wskazanie, że „zadania konsula wykonuje kapitan statku” (z nieznanych mi przyczyn analogicznej regulacji zabrakło - co poczytuję za błąd Państwowej Komisji Wyborczej - w trzeciej uchwale, w przypadku której jedynie w części wstępnej załączonych do niej wytycznych stwierdzono, że ilekroć mowa jest w nich o konsulu, „należy przez to rozumieć odpowiednio kapitana statku”26). Z kolei, $\S 2$ pkt 3 wszystkich trzech uchwał postanawia o możliwości zarządzenia przez komisję obwodową wcześniejszego (nie wcześniej jednak niż o godz. 18) zakończenia głosowania pod warunkiem oddania głosów przez wszystkich do tego uprawnionych; łaskawość okazana przez PKW jest w tym względzie najzupełniej zbędna, skoro wcześniejsze zakończenie głosowania po oddaniu głosu przez wszystkich wyborców może być zarządzone przez komisję obwodową na podstawie art. $39 \S 7 \mathrm{kw}$ - jest to nie tylko superfluum, ale i jaskrawe naruszenie „Zasad techniki prawodawczej”"27. Punkt 9 pierwszych i trzecich oraz pkt 10 drugich wytycznych stanowią, że komisja obwodowa ${ }^{28}$ powinna znać numery telefonów, pod którymi pełnione są dyżury w konsulacie i w Ministerstwie Spraw Zagranicznych - tak sformułowana dyspozycja wobec komisji na statkach morskich jest tyleż nietrafna, co martwa, ważne bowiem jest to, by komisja ta posiadała kontakt radiotelefoniczny z kapitanem i oficerem wachtowym. Punkt 13 pierwszych wytycznych oraz pkt 14 pozostałych nakazuje podanie przed wyborami na stronie internetowej konsula informacji

${ }^{25}$ M. P. 2015, poz. 1020.

${ }^{26}$ Analogicznej wykładni dokonała PKW - nie wiedzieć, po co - w części wstępnej również drugich wytycznych.

${ }^{27}$ I to skutecznych wobec aktów prawnych stanowionych przez PKW, gdyż ustanowionych rozporządzeniem Prezesa Rady Ministrów z 20 czerwca 2002 r. w sprawie „Zasad techniki prawodawczej” (Dz. U. 2016, poz. 283) - zob. M. Bogusz [2010: 91-98].

${ }^{28}$ Ilekroć w niniejszym tekście mowa o komisji obwodowej, należy przez to rozumieć zarówno obwodową komisję wyborczą, jak i obwodową komisję do spraw referendum, o ile z kontekstu nie wynika, że nazwa ta występuje jako synonim tylko jednej z nich. 
o godzinie rozpoczęcia pracy komisji w dniu głosowania - i tym razem PKW nie dostosowała wymogów wobec wyborów za granicą do realiów panujących na statku; przecież kapitan tegoż, nie będąc w odróżnieniu od konsula organem państwowym, nie ma obowiązku prowadzenia strony internetowej. Owszem, strony internetowe posiadają większość armatorów i niektóre statki, trudno byłoby jednak mówić o stronach www samych kapitanów. Punkt 14 pierwszych oraz pkt 15 pozostałych wytycznych dotyczą odbierania przez komisję kart do głosowania i innych dokumentów ${ }^{29}$ od pracowników konsulatu, natomiast pkt 79 drugich wytycznych i pkt 90 trzecich odnoszą się do przechowywania dokumentów z już przeprowadzonego głosowania w konsulacie, jako depozyt przekazany przez przewodniczącego komisji obwodowej ${ }^{30}$. Jakkolwiek kapitan statku jest grosso modo odpowiednikiem konsula, żadnego odzwierciedlenia na statku nie ma termin „konsulat”; nie ma na nim „kapitanatu”, nie wiadomo zatem, w jaki sposób należałoby odnosić do okrętowego życia wytyczne PKW w zakresie udziału konsulatu i jego pracowników w przekazywaniu i przyjmowaniu dokumentów i pieczęci komisji obwodowej. W moim przekonaniu to kapitan ma wykonywać kompetencje i konsula, i konsulatu, i pracowników konsulatu $^{31}$; sam sobie, nomen omen, sterem, żeglarzem i okrętem.

Ponadto, w punkcie 7 każdych wytycznych czytamy, iż w lokalu komisji powinno znajdować się godło RP. Nie negując meritum owej „powinności” zastanawiam się nad sensem ujmowania jej w akcie prawnym rangi załącznika do uchwały PKW. Art. 9 ust. 1 ustawy z 31 stycznia 1980 roku o godle, barwach i hymnie Rzeczypospolitej Polskiej oraz o pieczęciach państwowych ${ }^{32}$ nakazuje polskim statkom morskim podnoszenie flagi państwowej z godłem jako bandery, z czego wnosić należy, że na statkach tych wyeksponowany jest jeden z symboli państwowych. Ekspozycja godła nie dotyczy statków lecz zlokalizowanych $\mathrm{w}$ ich obrębie komisji obwodowych. Jako że należy zaliczyć je do organów administracji państwowej [por. Sokala, Święcki 2007: 177178], kwestię używania przez komisje godła państwowego reguluje ustawa z 31 stycznia 1980 roku Co prawda, komisji obwodowych nie sposób zaliczyć do wskazanych $\mathrm{w}$ art. 2a podmiotów, które używają wizerunku orła ustalonego dla godła (w tym ani do organów władzy państwowej, o których mowa w pkt 1, ani do organów administracji rządowej, o których stanowi pkt 2), jednakże jego pkt 13 zobowiązuje do tego również inne podmioty, jeżeli przepisy szczególne (choćby uchwała PKW) uprawniają je do używania wizerunku orła.

${ }^{29}$ Także przedmiotu niebędącego dokumentem w postaci pieczęci komisji obwodowej.

${ }^{30}$ Tym razem - à rebours - w depozyt oddawana jest i pieczęć, o której mowa w poprzednim przypisie.

${ }_{31}$ Będzie o tym mowa niżej przy komentowaniu aktu ministra kultury i dziedzictwa narodowego.

${ }^{32}$ Dz. U. 2016, poz. 625 ze zm. 
Niezależnie od tego, art. 3 ust. 1 pkt 1 decyduje o umieszczaniu godła w pomieszczeniach urzędowych należących do organów państwowych (a więc już nie tylko organów władzy państwowej) ${ }^{33}$, a i tak wedle ust. 2 godło można umieszczać $\mathrm{w}$ innych miejscach niż wymienione w ust. 1, byle z uwzględnieniem art. 1 ust. 2, dotyczącego otaczania symboli RP czcią i szacunkiem jako prawa i obowiązku m.in. wszystkich organów państwowych). Punkt 7 wytycznych drugich i trzecich stanowią ponadto: „Niedopuszczalne jest użycie jako urny na karty do głosowania ${ }^{34}$ przedmiotów, których codzienne przeznaczenie powoduje, że wykorzystanie ich jako urny naruszałoby powagę głosowania". Po pierwsze, tak bezwzględnie wydany zakaz jest wyrazem zbędnego patosu, który głosowaniu wcale powagi nie doda, lecz może je ośmieszyć; po drugie, PKW raczyła nie wziąć pod uwagę kardynalnego znaczenia jakie mają dla statku oszczędność miejsca, ekonomika przestrzeni, unikanie przewożenia zbytecznych gabarytów, których obecność, np. na drodze ewakuacyjnej, może stanowić zagrożenie tyleż dla bezpieczeństwa statku, co zdrowia i życia ludzi. Moim zdaniem należałoby bardziej liberalnie ustosunkować się do możliwości wykorzystania na statku różnych przedmiotów, które można jednorazowo wykorzystać jako urnę wyborczą.

Wreszcie pkt 2 wszystkich trzech wytycznych wyposaża przewodniczącego komisji obwodowej w prawo zażądania opuszczenia lokalu przez osobę naruszającą porządek i spokój, a w razie potrzeby zwrócenia się „do odpowiednich służb o zapewnienie koniecznej pomocy". Rzecz nie tylko w tym, że to kolejne naruszenie $\S 137$ ztp (zbędne powtórzenie przepisu ustawy - ściślej art. $49 \S 2$ $\mathrm{kw}$ ), ale i w tym, że wykonanie kompetencji przewodniczącego komisji może okazać się na statku problematyczne, także przez wzgląd na kodeksowo umocowane porządkowe uprawnienia kapitana. Może on mianowicie zatrzymać w osobnym pomieszczeniu osobę, której zachowanie na statku zagraża bezpieczeństwu statku, ludzi i mienia (art. $68 \S 1 \mathrm{~km}$ ) [zob. Młynarczyk 2002: 113, 202-203] ${ }^{35}$, gdyby zaś na statku popełniono przestępstwo, kapitan ma m.in. obowiązek zabezpieczenia dowodów, zawiadomienia prokuratora w siedzibie portu macierzystego, przedsięwzięcia środków odpowiednich dla zapobieżenia uchyleniu osoby podejrzanej od odpowiedzialności karnej, tudzież przekazania tej osoby, wraz z zawiadomieniem o popełnieniu przestępstwa, właściwemu organowi w polskim porcie, do którego statek zawinie, lub jednostce pływającej marynarki wojennej, straży granicznej bądź policji (art. $72 \S 1 \mathrm{~km}^{36}$ [zob.

\footnotetext{
${ }^{33}$ Mimo to, w pkt 4 wskazano expressis verbis na urzędy konsularne.

34 W pkt 7 trzecich wytycznych „urny wyborczej”.

35 Przychylam się do zdania G. Sidor [2014: 212-213], według której jest to zatrzymanie porządkowe (prewencyjne).

${ }^{36}$ I tym razem zgadzam się z Sidor [2014: 217-221] kwalifikującą to zatrzymanie jako zatrzymanie właściwe.
} 
Młynarczyk 2002: 117; Radwański 2008b: 49; Zyzda 2015: 183-184; szerzej Woźniewski 2013: 279-290], § 2-7 rozporządzenia Ministra Infrastruktury z 23 lutego 2005 roku w sprawie trybu postępowania kapitana statku wobec osoby podejrzanej o popełnienie przestępstwa przeciwko bezpieczeństwu żeglugi morskiej ${ }^{37}$ ). Czy możliwe jest, by przewodniczący komisji, zażądawszy (nieskutecznie) opuszczenia lokalu przez awanturnika zwrócił się do kapitana jako jedynej dostępnej spośród „odpowiednich służb”, a ten zapewnił „konieczną pomoc" poprzez dokonanie zatrzymania prewencyjnego lub właściwego? Na pierwszą część pytania należy odpowiedzieć twierdząco, druga jednak jest bardziej dyskusyjna. Skoro kapitan działa (a powinien działać) na podstawie i w granicach prawa, może zatrzymać osobę zachowującą się w sposób zagrażający bezpieczeństwu m.in. ludzi i mienia, jeśli zatem osoba ta stanowiła niebezpieczeństwo czy to dla składu komisji, czy dla jej dokumentów, dla wyborców, dla lokalu i jego wyposażenia, zatrzymanie porządkowe jest dopuszczalne. Co się tyczy zatrzymania właściwego, można dokonać go pod warunkiem popełnienia w lokalu wyborczym przestępstwa stypizowanego w Kodeksie wyborczym (zwłaszcza w art. 494 § 1), Kodeksie karnym (np. w art. 137 $\S 1$, art. $222 \S 1$, art. 223 , art. $224 \S 1$, art. $226 \S 1$, art. 248 pkt 3 i 5, art. 249 pkt 3 czy art. 250-251) lub innej ustawie karnej.

Abstrahując od uprawnień przysługujących kapitanowi w razie zaistnienia zagrożenia dla porządku i spokoju na statku w dniu głosowania, należy pamiętać o jego istotnej kompetencji par excellence profilaktycznej, prewencyjnej. Otóż na podstawie $\S 4$ rozporządzenia Ministra - Kierownika Urzędu Gospodarki Morskiej z 7 maja 1983 roku w sprawie zasad i warunków sprzedaży, podawania i spożywania napojów alkoholowych na morskich statkach handlowych w żegludze międzynarodowej oraz w międzynarodowych portach morskich ${ }^{38}$ kapitan może - ze względu na bezpieczeństwo i porządek na statku - wprowadzić całkowity lub częściowy zakaz sprzedaży, podawania i spożywania napojów alkoholowych na statku. Zważywszy na istotną rolę nadużytego alkoholu jako motoru zachowań o chuligańskim charakterze, warto byłoby oczekiwać od kapitanów stosowania tego przepisu w obliczu nadchodzących wyborów (referendum).

W myśl art. 39 § $6 \mathrm{kw}$ każde z głosowań na polskim statku morskim odbywa się w godzinach 7-21 czasu miejscowego w każdym dniu głosowania, przy czym jeśli głosowanie miałoby być zakończone w dniu następnym po głosowaniu w kraju, przeprowadza się je w dniu poprzedzającym. Art. $39 \S 7$ umożliwia obwodowej komisji wyborczej na statku wcześniejsze zakończenie głosowania w sytuacji, w której wszyscy wyborczy wpisani do spisu wyborców oddali

37 Dz. U. 2005, nr 42, poz. 405.

38 Dz. U. 1983, nr 25, poz. 121. 
już swój głos, nie wcześniej jednak niż o godz. 18. O zakończeniu głosowania przewodniczący komisji obwodowej niezwłocznie powiadamia kapitana (choć z art. 39 § 7 nie stwierdzono tego explicite) i właściwą komisję wyborczą wyższego stopnia. Głosowanie dwudniowe odbywa się na statku na zasadach ogólnych, przy czym to na kapitanie ciąży obowiązek ochrony lokalu komisji w czasie przerwy w głosowaniu (art. $47 \S 3$ i $\S 8$ pkt 5) ) $^{39}$; również kapitan zapewnia ochronę tegoż lokalu zamkniętego wskutek nadzwyczajnych wydarzeń (art. $47 \S 7$ ). Nie kto inny jak kapitan statku zapewnia również dostępność kopert na karty do głosowania (art. $52 \S 9$ pkt 3 ).

Wyniki głosowania z obwodów utworzonych statkach są przekazywane okręgowej komisji wyborczej właściwej dla dzielnicy Śródmieście m. st. Warszawy (art. $78 \S 2$ ), po czym przewodniczący komisji obwodowej przekazuje niezwłocznie kapitanowi w depozyt dokumenty z głosowania i pieczęć komisji (art. $79 \S 1)^{40}$. Kapitan zapewnia obsługę i techniczno-materialne warunki pracy obwodowej komisji wyborczej, w tym możliwość wykorzystania techniki elektronicznej, oraz wykonanie zadań związanych z organizacją i przeprowadzeniem wyborów na statku (art. $156 \S 1$ i 5). Zapewnienie obsługi i techniczno-materialnych warunków pracy obwodowej komisji do spraw referendum również stanowi obowiązek kapitana (art. 18 ust. 2 i 3 ustawy z 14 marca 2003 r.).

5. Kapitan powołuje obwodową komisję wyborczą [zob. Sokala 2011: 151] spośród wyborców (art. $183 \S 5 \mathrm{kw}$ ) tak jak czyni to wójt gminy, w tym losując publicznie skład komisji w przypadku zgłoszenia doń większej niż dopuszczalna liczby kandydatów (art. $182 \S 7$ ), uzupełniając skład, jeśli suma kandydatur jest mniejsza od dopuszczalnego minimalnego składu komisji (art. 182 § 8), tudzież zwołując pierwsze posiedzenie komisji (art. $182 \S 9$ ), na którym komisja ta wybiera przewodniczącego i jego zastępcę (art. 182 § 10). Skład komisji wyborczej na statku wynosi od czterech do sześciu osób spośród kandydatów zgłoszonych przez pełnomocników wyborczych lub upoważnione przez nich osoby oraz jedna osoba spośród pracowników statku, na którym utworzony jest obwód głosowania (art. 182 § 3). Podobnie jest z powoływaną przez kapitana $\mathrm{z}$ grona osób uprawnionych do udziału w referendum obwodową komisją do spraw referendum, przy czym liczy ona od pięciu do siedmiu osób, a jedną z nich wskazuje kapitan (art. 14 ustawy z 14 marca 2003 r.).

O marginalnym par excellence znaczeniu głosowania w wyborach do Sejmu odbywanego na polskich statkach morskich świadczy ewidentnie art. $230 \S 2$ kw, według którego, jeśli w wyborach do Sejmu właściwa okręgowa komisja

\footnotetext{
39 Również w referendum ogólnokrajowym (art. 32 ust. 8 ustawy z 14 marca 2003 r.).

${ }^{40}$ Wyniki głosowania i protokół z referendum trafia natomiast do komisarza wyborczego właściwego dla siedziby armatora statku (art. 26 ust. 2 ustawy z 14 marca 2003 r.).
} 
wyborcza nie otrzyma wyników tam przeprowadzonego głosowania w ciągu 24 godzin od jego zakończenia, głosowanie w tych obwodach uważa się za niebyłe, odnotowując to w protokole wyników głosowania w okręgu, z wymienieniem obwodów oraz ewentualnych przyczyn nieuzyskania z nich wyników głosowania. Jeśli chodzi o wybory do Senatu, nieuzyskanie przez właściwą okręgową komisję wyborczą wyników głosowania na statkach w ciągu 24 godzin od jego zakończenia, głosowanie w tych obwodach uważa się za niebyłe, odnotowując to w protokole wyników głosowania na zasadach przewidzianych w wyborach do Sejmu (art. $272 \S 2$ ). W identyczny sposób proceduje się w wyborach prezydenta RP (art. $314 \S 2$ ) i wyborach do Parlamentu Europejskiego (art. $353 \S 2$ ).

Wyborca przebywający na statku może - w terminie siedmiu dni od dnia ogłoszenia wyników wyborów (referendum) przez PKW w Dzienniku Ustaw (trzy dni w przypadku wyborów prezydenckich) - wnieść protest przeciwko ważności wyborów do Sejmu i Senatu, wyborów prezydenta, wyborów do PE i referendum ogólnokrajowego składając go na piśmie kapitanowi statku, przy czym musi on zarazem dołączyć do protestu zawiadomienie o ustanowieniu swojego pełnomocnika zamieszkałego w kraju lub pełnomocnika do doręczeń zamieszkałego w kraju, pod rygorem pozostawienia protestu bez biegu [zob. Buczkowski 2011: 224] (art. $241 \S 1$ i 2, art. 258, art. 318 § 3, art. 321 § 1 i 2, art. 336 kw, art. 34 ustawy z 14 marca 2003 r.). Należy sądzić, że w świetle art. $9 \S 1 \mathrm{kw}$ termin do wniesienia protestu równoznaczny jest $\mathrm{z}$ dniem jego złożenia bezpośrednio kapitanowi.

6. Jeśli wziąć pod uwagę ostatnie chronologicznie wybory parlamentarne i prezydenckie oraz referendum ogólnokrajowe należy zapoznać się ze sposobem wykorzystania przez ministra infrastruktury i rozwoju przysługującego mu a zawartego w art. $15 \S 3$ Kodeksu wyborczego uprawnienia do tworzenia obwodów głosowania na polskich statkach morskich. Rozporządzeniem z 24 kwietnia 2015 roku w sprawie utworzenia obwodów głosowania na polskich statkach morskich w wyborach Prezydenta Rzeczypospolitej Polskiej ${ }^{41}$ utworzono takowe obwody w zawrotnej liczbie dwóch, a to na MODU „Baltic Beta” (obwód 1000) i MODU „LOTOS Petrobaltic” (obwód 1001). Te same jednostki, tym razem oznaczone numerami obwodów odpowiednio 1001 i 1002, oraz RV „Oceania” (obwód 1000) i STS „Dar Młodzieży” (obwód 1003) znalazły się w wykazie obwodów stanowiących załącznik do rozporządzenia z 28 sierpnia 2015 roku w sprawie utworzenia obwodów głosowania dla wyborców przebywających na polskich statkach morskich w referendum ogólnokrajowym wyznaczonym na dzień 6 września 2015 roku $^{42}$ RV „Oceania” (obwód 1000),

${ }^{41}$ Dz. U. 2015, poz. 590.

${ }^{42}$ Dz. U. 2015, poz. 1287. 
MODU „Baltic Beta” (1003) i MODU „LOTOS Petrobaltic” (1004), a także RV „Baltica” (1001) i STS „Lê Quý Đôn” (1002) znaleźć można w analogicznym wykazie załączonym do rozporządzenia z 16 października 2015 roku w sprawie utworzenia obwodów głosowania na polskich statkach morskich w wyborach do Sejmu Rzeczypospolitej Polskiej i do Senatu Rzeczypospolitej Polskiej ${ }^{43}$. Do 31 grudnia 2015 roku o utworzenie obwodów głosowania na statkach wnosił armator (kapitan statku zastąpił go w tym zakresie na mocy art. 1 pkt 2 ustawy z 25 czerwca 2015 roku o zmianie ustawy - Kodeks wyborczy ${ }^{44}$ ). Jeśli zwrócić uwagę na jedyny wniosek armatora (LOTOS Petrobaltic S.A.) złożony do ministra infrastruktury i rozwoju przed wyborami prezydenckimi, odnotować należy powołanie się w nim na postanowienie Marszałka Sejmu z 4 lutego 2015 roku o zarządzeniu wyborów Prezydenta Rzeczypospolitej Polskiej ${ }^{45}$, tudzież wskazanie, że obie objęte wnioskiem platformy wiertnicze znajdować się będą w dniu głosowania w polskiej strefie ekonomicznej Morza Bałtyckiego i spełniają kodeksowe wymogi zarówno co do liczebności wyborców (ok. 50 pracowników na jednej zmianie), jak i procedowania po zakończeniu głosowania (możliwość przekazania jego wyników Okręgowej Komisji Wyborczej w Gdańsku ${ }^{46}$. Podobny wniosek złożony przez tegoż armatora do tego samego adresata przed referendum ogólnokrajowym skonstruowano analogicznie, z powołaniem na postanowienie Prezydenta RP z 17 czerwca 2015 roku o zarządzeniu ogólnokrajowego referendum ${ }^{47}$ i ze wskazaniem identycznej liczebności potencjalnych uczestników głosowania ${ }^{48}$. Pozostali armatorzy nie odnosili się do postanowienia Prezydenta, zawarli jednak we wnioskach informacje o przewidywalnej liczebności załogi: jeśli chodzi o STS „Dar Młodzieży”, który w dniu referendum miał odbywać rejs z Londynu do Gdyni, Akademia Morska w Gdyni zapowiedziała zaokrętowanie ok. 35 członków załogi i ok. 120 studentów odbywających praktyki morskie ${ }^{49}$, natomiast Instytut Oceanologii Polskiej Akademii Nauk, kierując skądinąd w sprawie RV „Oceania” wniosek nie do ministra lecz Ministerstwa Infrastruktury i Rozwoju, stwierdził, że podczas referendum statek „będzie w morzu” i oszacował przewidywalną „ilość załogi”

43 Dz. U. 2015, poz. 1650.

44 Dz. U. 2015, poz. 1043.

45 Dz. U. 2015, poz. 188.

46 Pismo prezesa zarządu, dyrektora naczelnego LOTOS Petrobaltic S.A. mgr. inż. Z. Paszkowicza do ministra infrastruktury i rozwoju mgr M. Wasiak z 31 marca 2015 r., NK/w/187/2015.

47 Dz. U. 2015, poz. 852.

48 Pismo prezesa zarządu, dyrektora naczelnego LOTOS Petrobaltic S.A. mgr. inż. Z. Paszkowicza do ministra infrastruktury i rozwoju mgr M. Wasiak z 20 lipca 2015 r., NK/w/550/2015.

49 Pismo kierownika Działu Armatorskiego Akademii Morskiej w Gdyni mgr K. Muszyńskiej do ministra infrastruktury i rozwoju mgr M. Wasiak z 30 lipca 2015 r. 
na 28 osób $^{50}$. Pora na wnioski armatorów o utworzenie obwodów głosowania w wyborach do Sejmu i do Senatu: pismo złożone przez LOTOS Petrobaltic S.A., podobnie jak w wypadkach wskazanych wyżej, zawierało przewidywaną liczbę wyborców na 50 osób $^{51}$ i powoływało się tym razem na postanowienie Prezydenta RP z 17 lipca 2015 roku w sprawie zarządzenia wyborów do Sejmu Rzeczypospolitej Polskiej i do Senatu Rzeczypospolitej Polskiej ${ }^{52}$; już w dniu ogłoszenia i wejścia w życie tego postanowienia analogiczny wniosek skierował (tym razem do ministra, a nadal zwiastując udział 28 wyborców) IO PAN ${ }^{53}$; przesłany nie do ministra, lecz do ministerstwa wniosek Morskiego Instytutu Rybackiego - Państwowego Instytutu Badawczego o utworzenie obwodu na RV „Baltica” odwoływał się do planowanego na dzień wyborów bałtyckiego rejsu tej jednostki, przekraczającej 15 osób liczebności członków załogi oraz możliwości technicznych przekazania właściwej okręgowej komisji wyborczej wyników głosowania niezwłocznie po jego zakończeniu ${ }^{54}$; wreszcie The Sail Training Association of Poland wniósł (także do ministerstwa) o utworzenie obwodu głosowania na STS „Lê Quý Đôn”, wskazując na art. 15 kw, określając nazwę i banderę jednostki, klasyfikując i ją i jej kapitana jako polskich, wreszcie wskazując armatora i właściciela (dwa różne podmioty) $)^{55}$.

Powracając do ubiegłorocznych wyborów i referendum muszę jednoznacznie stwierdzić, że wśród sześciu jednostek, na których (w liczbie od dwóch dopięciu) tworzono obwody głosowania, nie było żadnego statku handlowego czy rybackiego, lecz wyłącznie statki żaglowe i badawcze oraz dwie samopodnośne platformy wiertnicze, których bezrefleksyjna, a dokonana przez ministra infrastruktury i rozwoju, kwalifikacja do rzędu polskich statków morskich nie jest bynajmniej aż tak oczywista i to nie tylko dlatego, że trudno jednoznacznie ocenić, czy te platformy znajdowały się ,w podróży” w dniu głosowania ${ }^{56}$.

${ }^{50}$ Pismo kierownika Zespołu Armatorskiego Instytutu Oceanologii Polskiej Akademii Nauk dr. inż. A. Kadłubickiego do Ministerstwa Infrastruktury i Rozwoju z 22 czerwca 2015 r., IO/ $\mathrm{TA} / 1111 / 15$.

${ }^{51}$ Pismo szefa Biura Zarządzania Zasobami Ludzkimi LOTOS Petrobaltic S.A. mgr K. Sowy do ministra infrastruktury i rozwoju mgr M. Wasiak z 15 września 2015 r., NK/w/753/2015.

${ }_{52}$ Dz. U. 2015, poz. 1017.

${ }^{53}$ Pismo zastępcy dyrektora ds. naukowych IO PAN prof. nadzw. IO PAN dr hab. K. Pazdro do ministra infrastruktury i rozwoju mgr M. Wasiak z 22 lipca 2015 r., IO/TA/1295/2015.

${ }_{54}$ Pismo dyrektora Morskiego Instytutu Rybackiego - Państwowego Instytutu Badawczego dr. E. .Kuzebskiego do Ministerstwa Infrastruktury i Rozwoju z 8 września 2015 r., DO/2727/52/2015.

${ }_{55}$ Pismo dyrektora, pełnomocnika armatora The Sail Training Association Poland M. Klebana do MIiR z 14 września 2015 r., 109/2015.

${ }^{56} \mathrm{Z}$ pisma prezesa zarządu, dyrektora naczelnego LOTOS Petrobaltic S.A. mgr. inż. Z. Paszkowicza do podsekretarza stanu w Ministerstwie Infrastruktury i Rozwoju dr hab. D. Pyć z 9 stycznia 2015 r. wynika, że spośród obu wskazanych wyżej platform statkiem morskim jest 
Można dopuścić zaistnienie sytuacji, w której po utworzeniu obwodu wyborczego na statku liczba wyborców spadnie poniżej minimalnej piętnastki. W wyborach prezydenta RP w 1995 roku nie przeprowadzono głosowania w obwodzie nr 1026 na MS „Budowlany” w wyniku decyzji kapitana, podjętej wskutek zmniejszenia się liczby uprawnionych do oddania głosu poniżej ówczesnego minimum wynoszącego 20 osób; na wniosek Polskiej Żeglugi Morskiej (armatora jednostki) Wojewódzka Komisja Wyborcza w Szczecinie zlikwidowała ten obwód [zob. Buczkowski 1996: 101, przyp. 275]. Wydaje się, że mimo zaistnienia tej sytuacji przed wejściem w życie Kodeksu wyborczego również pod jego rządami należy postępować w takim wypadku w analogiczny sposób.

7. W wyborach do Sejmu i do Senatu w 2011 roku, w wyborach do PE w 2014 roku i w wyborach prezydenta w 2015 roku stosowana była uchwała PKW z 16 maja 2011 roku w sprawie trybu i terminu powoływania obwodowych komisji wyborczych w obwodach głosowania utworzonych na polskich statkach morskich ${ }^{57}$. W wyborach do Sejmu i do Senatu w 2015 roku stosowano uchwałę PKW z 16 września 2015 roku w sprawie trybu i terminu powoływania obwodowych komisji wyborczych w obwodach głosowania utworzonych na polskich statkach morskich ${ }^{58}$. Wreszcie, w referendum ogólnokrajowym w 2015 roku znalazła zastosowanie uchwała PKW z 6 lipca 2015 roku w sprawie trybu i terminu powoływania obwodowych komisji do spraw referendum w obwodach głosowania utworzonych na polskich statkach morskich W referendum ogólnokrajowym ${ }^{59}$, wydana na podstawie art. 14 ust. 1 ustawy z 14 marca 2003 roku Jako że obowiązują obecnie obie, niemal bliźniaczo podobne uchwały z 2015 roku, należy poświęcić ich regulacjom kilka uwag. Paragraf 3 każdej z nich nadaje kapitanowi kompetencję do wydawania pisemnej decyzji w sprawie powołania obwodowej komisji najpóźniej na trzy dni przed dniem wyborów (referendum), natomiast § 4-5 każdej reguluje tryb wnoszenia zgłoszeń kandydatów do komisji, a § 6 - właściwość kapitana do rozpatrywania zgłoszeń i wymogi stawiane kandydatom do składu komisji. W świetle § 7

\footnotetext{
„LOTOS Petrobaltic”, natomiast „Baltic Beta” nie ma przymiotu statku, została wykreślona z rejestru statków i stanowi obiekt budowlany (morską budowlę hydrotechniczną). Nadawca wyjaśnia ponadto, że kierowana przezeń spółka stanowi zakład górniczy, podlejący przepisom ustawy z 29 czerwca 2011 r. - Prawo geologiczne i górnicze (Dz. U. 2016, poz. 1131 ze zm.), posiadający morskie jednostki, w tym platformy samopodnośne, o czym $\S 367$ ust. 1 pkt 1 lit. c rozporządzenia Ministra Gospodarki z 25 kwietnia 2014 r. w sprawie szczegółowych wymagań dotyczących prowadzenia ruchu zakładów górniczych wydobywających kopaliny otworami wiertniczymi (Dz. U. 2014, poz. 812).

${ }_{57}$ M. P. 2011, nr 44, poz. 476.

${ }_{58}^{58}$ M. P. 2015, poz. 926.

${ }^{59}$ M. P. 2015, poz. 632.
} 
każdej z uchwał, jeżeli liczba prawidłowo zgłoszonych kandydatów wynosi od czterech do sześciu, kapitan powołuje w skład komisji wszystkich kandydatów oraz jednego członka komisji spośród członków załogi, a w przypadku braku takiej możliwości - wyborcę (uprawnioną osobę) przez siebie wskazanego. Jeśli liczba prawidłowo zgłoszonych kandydatur jest mniejsza od czterech, kapitan powołuje komisję pięcioosobową, w tym wszystkie te kandydatury oraz członkowie załogi lub inni wyborcy ( 99 każdej uchwały), gdyby natomiast, o czym powiada $\S 8$, przekraczała ona sześć, kapitan powoła komisję siedmioosobową, z czego sześciu członków wyłania w drodze publicznego losowania, natomiast jednego członka komisji powołuje spośród członków załogi, a w braku takiej możliwości - wskazanego przez siebie wyborcę (osobę uprawnioną). Pozostałe zawarte w obu uchwałach kompetencje kapitana statku obejmują niezwłoczne podanie do publicznej wiadomości składu komisji - zarówno w miejscu przeznaczonym na informacje dla załogi, jak i w siedzibie komisji (§ 10 ust. 1 każdej z uchwał) oraz uzupełnienie składu komisji w przypadku wygaśnięcia członkostwa powodującego zmniejszenie się jej składu poniżej pięciu osób ( $\$ 11$ każdej z uchwał).

Na podstawie art. $40 \S 5$ Kodeksu wyborczego PKW ustala wzory kart do głosowania również dla obwodów na statkach morskich, na dowód czego przywołać należy uchwały PKW z 3 lutego 2014 roku w sprawie wzorów kart do głosowania w wyborach do Parlamentu Europejskiego dla obwodów głosowania utworzonych za granicą i na polskich statkach morskich ${ }^{60}, \mathrm{z} 4$ lutego 2015 roku w sprawie wzorów kart do głosowania dla obwodów głosowania utworzonych za granicą i na polskich statkach morskich w wyborach Prezydenta Rzeczypospolitej Polskiej w 2015 roku $^{61}$ oraz z 3 września 2015 roku w sprawie wzorów kart do głosowania w wyborach do Sejmu Rzeczypospolitej Polskiej i do Senatu Rzeczypospolitej Polskiej dla obwodów głosowania utworzonych za granicą i na polskich statkach morskich ${ }^{62}$.

Na przestrzeni lat 2014-2015 zauważalna jest ewolucja poglądu Państwowej Komisji Wyborczej odnośnie do praktycznej strony przekazywania kart do głosowania dla utworzonych na statkach obwodów. Pierwotnie, w $\S 1$ uchwały z 10 lutego 2014 roku w sprawie sposobu sporządzania i przekazania kart do głosowania dla obwodów głosowania utworzonych na polskich statkach morskich w wyborach do Parlamentu Europejskiego w 2014 roku $^{63}$ oraz w $§ 1$ uchwały z 23 lutego 2015 roku w sprawie sposobu sporządzania i przekazania kart do głosowania dla obwodów głosowania utworzonych na polskich

$\begin{array}{ll}{ }^{60} & \text { M. P. 2014, poz. } 139 . \\ { }^{61} & \text { M. P. 2015, poz. } 153 . \\ { }^{6} & \text { M. P. 2015, poz. } 846 . \\ { }^{63} & \text { M. P. 2014, poz. } 179 .\end{array}$ 
statkach morskich w wyborach Prezydenta Rzeczypospolitej Polskiej w 2015 roku $^{64}$ komisja wyszła z założenia o wykonywanej niezwłocznie, po ustaleniu przez kapitanów statków liczby wyborców ujętych w spisach, kompetencji armatorów do zapewnienia dostarczenia do obwodów głosowania na statkach kart wydrukowanych i przekazanych przez okręgową komisję wyborczą właściwą dla siedziby armatora. Dopiero gdyby do siódmego dnia przed dniem wyborów kapitan nie otrzymał kart wydrukowanych w kraju, nabywał on na podstawie $\S 2$ ust. 1 każdej z uchwał obowiązek sporządzenia kart w brzmieniu przekazanym przez komisję okręgową według wzoru i w sposób określony w uchwałach PKW odpowiednio z 3 lutego 2014 i 4 lutego 2015 roku (wtedy - o czym mowa w $\S 2$ ust. 2 każdej uchwały - w miejsce pieczęci komisji okręgowej umieszczano odcisk pieczęci kapitana). Inaczej w tym względzie przedstawia się uchwała PKW z 3 sierpnia 2015 roku w sprawie zasad drukowania i przekazania kart do głosowania dla obwodów głosowania utworzonych na polskich statkach morskich $\mathrm{w}$ referendum ogólnokrajowym zarządzonym na dzień 6 września 2015 roku $^{65}$, albowiem - nie nadając w tym zakresie jakiejkolwiek kompetencji armatorom - zdecydowano w § 1, iż to kapitan, najpóźniej na sześć dni przed dniem referendum, sam sporządzi karty do głosowania $\mathrm{w}$ brzmieniu przekazanym przez komisarza wyborczego właściwego dla siedziby armatora ${ }^{66}$, przy czym w miejscu przeznaczonym na pieczęć PKW drukuje się lub odciska pieczęć kapitana (§ 1 pkt 2). W ślad za tą regulacją podążyła analogiczna uchwała PKW z 16 września 2015 roku w sprawie sposobu sporządzania i przekazania kart do głosowania dla obwodów głosowania utworzonych na polskich statkach morskich w wyborach do Sejmu Rzeczypospolitej Polskiej i do Senatu Rzeczypospolitej Polskiej, zarządzonych na dzień 25 października 2015 roku $^{67}$, z tą różnicą, że miast komisarza wyborczego jest w niej mowa - co oczywiste - o właściwej dla siedziby armatora okręgowej komisji wyborczej, zaś odniesienie do uchwały PKW z 3 września 2015 roku zastępuje odwołanie do uchwały z 22 czerwca 2015 roku $^{68}$

${ }^{64}$ M. P. 2015, poz. 252.

${ }^{65}$ M. P. 2015, poz. 709.

${ }^{66}$ Według wzoru i w sposób określony w uchwale PKW z 22 czerwca 2015 r. w sprawie wzorów karty do głosowania oraz nakładki na kartę do głosowania sporządzonej w alfabecie Braille'a w referendum ogólnokrajowym zarządzonym na dzień 6 września 2015 r. (M. P. 2015, poz. 572), jednakże z wyłączeniem wymogów określonych w $§ 1$ ust. 1 pkt. 2-3 tej uchwały oraz szczegółowych wymogów technicznych zawartych w załączniku do niej.

${ }^{67}$ M. P. 2015, poz. 914.

${ }^{68}$ Wspólny mianownik dla czterech uchwał PKW przywołanych w tym akapicie stanowi zawarta w nich ( 33 uchwał z 10 lutego 2014 r. i 23 lutego 2015 r., § 2 uchwał z 3 sierpnia i 16 września 2015 r.) kompetencja kapitana do przekazania obwodowej komisji wyborczej (obwodowej komisji ds. referendum) za pokwitowaniem kart otrzymanych lub przez siebie sporządzonych (w przypadku dwóch ostatnich uchwał wyłącznie przez siebie sporządzonych). 
Porządkowych kompetencji kapitana wykonywanych w czasie przerwy w głosowaniu dotyczą rozporządzenia - Ministra Infrastruktury z 30 kwietnia 2003 roku w sprawie szczegółowych wymagań oraz obowiązków kapitana polskiego statku morskiego w zakresie ochrony lokalu obwodowej komisji do spraw referendum w czasie przerwy w głosowaniu ${ }^{69}$ oraz Ministra Infrastruktury i Rozwoju z 21 kwietnia 2015 roku w sprawie szczegółowych wymagań oraz obowiązków kapitana polskiego statku morskiego w zakresie ochrony lokalu wyborczego w czasie przerwy w głosowaniu spowodowanej nadzwyczajnymi wydarzeniami ${ }^{70}$. Paragraf 1 pierwszego rozporządzenia oraz $\S 2$ ust. 1 i $\S 3$ ust. 1 drugiego nakazują kapitanowi wyznaczenie pomieszczenia na taki lokal, tudzież zapewnienie zamknięcia go w czasie przerwy w głosowaniu w sposób uniemożliwiający dostanie się doń osób nieupoważnionych ${ }^{71}$. Kapitan uczestniczy również w otwieraniu i zamykaniu lokalu przez przewodniczącego komisji obwodowej oraz weryfikacji nienaruszalności pieczęci komisji przed rozpoczęciem głosowania po przerwie, a także przechowuje klucze w kasie pancernej (§ 2 ust. 1-4 pierwszego rozporządzenia, $\S 3$ ust. 2-5 drugiego $^{72}$ ). Ponadto, pierwsze ( $(3)$ i drugie rozporządzenie ( $\$ 4$ ust. $2-3$ ) regulują kompetencje kapitana w zakresie uniemożliwienia zamiaru wtargnięcia do lokalu osoby nieupoważnionej (rozporządzenie pierwsze) bądź zapobieżenia skutkom wtargnięcia już dokonanego (drugie). Zaskakująca jest zarówno ta rozbieżność w konstruowaniu obowiązków kapitana względem dokonania lub zamiaru wtargnięcia, jak i zawarta w $\S 2$ ust. 5 pierwszego rozporządzenia i $\S 3$ ust. 6 drugiego dyspozycja nakazująca mu wyznaczenie członka załogi statku do zapewnienia stałej ochrony lokalu w czasie przerwy w głosowaniu $^{73}$. Wątpliwości z mojej strony budzi prawna podstawa kompetencji kapitana

${ }^{69}$ Dz. U. 2003, nr 75, poz. 675.

${ }^{70}$ Dz. U. 2015, poz. 576.

${ }^{71} \S 2$ ust. 2 rozporządzenia z 21 kwietnia 2015 r. zobowiązuje ponadto kapitana, by „w miarę możliwości” lokal wyborczy wyposażony był „w środki zabezpieczenia technicznego takie jak wzmocnione drzwi i co najmniej jeden zamek". W tym i w kolejnych 2 przypisach pod pojęciem rozporządzenia z 21 kwietnia 2015 r. rozumiem akt dotyczący ochrony lokalu, nie zaś przywołany wcześniej dotyczący spisu wyborców.

$72 \S 3$ ust. 5 rozporządzenia z 21 kwietnia 2015 r. powiada, że kapitan przechowuje klucze „w kasie pancernej znajdującej się na statku lub w innym miejscu, do którego kapitan statku ma wyłączny dostęp”. Ciekaw jestem, o jakie „inne miejsce” chodzi - o kapitańską kawalerkę czy skrytkę depozytową w banku - i w jakim celu kapitan miałby udawać się na ląd celem pozostawienia i odbioru kluczy. A może miałby je holować za statkiem?

${ }^{73}$ Rozporządzenie z 21 kwietnia 2015 r. uprawnia ponadto kapitana „w każdym czasie” do zmiany wyznaczonego członka załogi ( 33 ust. 6) oraz upoważnia owego załoganta do podjęcia działań uniemożliwiających wtargnięcie do lokalu osoby nieupoważnionej, tudzież zobowiązuje go do poinformowania kapitana „najszybciej jak to jest możliwe” o podjętych działaniach (§ 4 ust. 1). 
do wyznaczania członka załogi do zapewnienia ochrony lokalu; zawartą w akcie prawnym rangi rozporządzenia można uznać ją za koherentną z art. $53 \S 2$ $\mathrm{km}$ nakazującym wszystkim obecnym na statku podporządkowanie się zarządzeniom kapitana wydawanym w celu zapewnienia bezpieczeństwa i porządku na statku, nie konweniuje ona jednak z ustawą z 5 sierpnia 2015 roku o pracy na morzu ${ }^{74}$, ochrona lokalu komisji obwodowej nie spełnia bowiem wymogów usprawiedliwiających pracę $\mathrm{w}$ godzinach nadliczbowych (art. 47 ust. 2), pozostawanie w gotowości do pracy (art. 48 ust. 1), czy pracę podczas akcji ratowniczej (art. 81 ust. 1).

Nieco uwagi warto poświęcić uchwałom PKW: z 17 lutego 2014 roku w sprawie zasad i trybu przekazywania okręgowej komisji wyborczej właściwej dla siedziby armatora wyników głosowania i protokołów głosowania z obwodów utworzonych na polskich statkach morskich w wyborach do Parlamentu Europejskiego $^{75}$, z 14 kwietnia 2015 roku w sprawie zasad i trybu przekazywania okręgowej komisji wyborczej właściwej dla siedziby armatora wyników głosowania i protokołów głosowania $\mathrm{z}$ obwodów utworzonych na polskich statkach morskich w wyborach Prezydenta RP, zarządzonych na dzień 10 maja $2015 \mathrm{roku}^{76}$, z 20 lipca 2015 roku w sprawie zasad i trybu przekazywania komisarzowi wyborczemu właściwemu dla siedziby armatora wyników głosowania i protokołów głosowania z obwodów utworzonych na polskich statkach morskich w referendum ogólnokrajowym zarządzonym na dzień 6 września 2015 roku $^{77}$, wreszcie z 16 września 2015 roku w sprawie zasad i trybu przekazywania okręgowej komisji wyborczej właściwej dla siedziby armatora wyników głosowania i protokołów głosowania z obwodów utworzonych na polskich statkach morskich w wyborach do Sejmu RP i do Senatu RP, zarządzonych na dzień 25 października 2015 roku $^{78}$ Jakkolwiek uchwały te obowiązują, śmiało można określić je jako praeterita - i dlatego, że (poza najstarszą) odnoszą się do wyborów zarządzonych na konkretną datę, i dlatego, że już w swoich tytułach wskazują na nieaktualną - w świetle znowelizowanego Kodeksu wyborczego - właściwość terytorialną komisji wyborczych. Czując się zwolniony z obowiązku szczegółowego omawiania unormowań, które najpewniej wkrótce ulegną zmianom ${ }^{79}$, pozwolę sobie zatrzymać się jedynie na minimum minimorum obejmującym kilka kluczowych kwestiach. Z punktów 10-11 załącznika

${ }^{74}$ Dz. U. 2015, poz. 1569 ze zm.

${ }^{75}$ M. P. 2014, poz. 181.

${ }_{76}$ M. P. 2015, poz. 346.

77 M. P. 2015, poz. 664.

${ }_{78}$ M. P. 2015, poz. 928.

79 Sądzę, że nie będzie już w nich miejsca na podział działających na statkach komisji obwodowych na korzystające i niekorzystające ze wspomagania informatycznego, powinien zaś zostać utrzymany, nałożony na przewodniczącego takiej komisji obwodowej, obowiązek przekazania kapitanowi jednego egzemplarza protokołu po zakończeniu głosowania. 
do każdej z czterech uchwał wynika, że armator niezwłocznie przekazuje właściwej komisji wyborczej (właściwemu komisarzowi wyborczemu) otrzymane od kapitanów statków protokoły głosowania, bądź sporządzone informacje o wynikach głosowania w obwodach, że w razie przedłużającego się oczekiwania na dane z któregokolwiek obwodu, armator podejmuje działania w celu ich uzyskania oraz że gdyby danych z obwodu w ciągu 24 godzin od zakończenia głosowania w obwodzie armator jednak nie uzyskał, informuje on właściwą komisję wyborczą (właściwego komisarza wyborczego) o przyczynach nieuzyskania danych, podając numery i siedziby tych feralnych obwodów. Punkt 12 każdego załącznika nakłada na kapitana obowiązek niezwłocznego po powrocie do kraju przekazania pozostających w jego rękach dokumentów i pieczęci komisji obwodowej armatorowi, który z kolei ma uczynić to samo wobec właściwej komisji wyborczej (właściwego komisarza wyborczego); wartym wspomnienia novum świadczącym o rozsądnym postrzeganiu specyfiki głosowania na morzu jest zawarte w pkt. 12 załącznika do najmłodszej z uchwał stwierdzenie, iż jeśli przejęte od kapitana dokumenty nie zostaną przekazane okręgowej komisji wyborczej do czasu jej rozwiązania, armator przekaże je dyrektorowi delegatury KBW, która obsługiwała ową komisję okręgową.

Prawodawca obarcza też kapitana statku istotnymi kompetencjami wykonywanymi już po zakończeniu pracy komisji obwodowych. Paragraf 4 ust. 1 rozporządzenia Ministra Kultury i Dziedzictwa Narodowego z 13 listopada 2013 roku w sprawie sposobu przekazywania, przechowywania i udostępniania dokumentów $\mathrm{z}$ wyboró $\mathrm{w}^{80}$ definiuje kapitana jako depozytariusza, który przy przekazywaniu i przechowywaniu dokumentów z wyborów stosuje spis zdawczo-odbiorczy, on to bowiem przyjmuje i przechowuje dokumenty z głosowania w komisji obwodowej (§ 6 ust. 1). Jak stanowi § 7, po upływie 30 dni od rozstrzygnięcia przez Sąd Najwyższy w sprawie ważności wyborów parlamentarnych i prezydenckich, tudzież od podjęcia uchwały SN w sprawie nieważności wyborów lub nieważności wyboru posła do PE, część dokumentów przechowywanych przez kapitana podlega brakowaniu (ust. 1), część zaś (dokumenty stanowiące materiały archiwalne wchodzące do państwowego zasobu archiwalnego) przekazuje on dyrektorowi właściwej delegatury KBW. Zbliżone regulacje zawiera rozporządzenie Ministra Kultury z 3 czerwca 2003 roku w sprawie sposobu przekazywania, przechowywania i udostępniania dokumentów z przeprowadzonego referendum ogólnokrajowego ${ }^{81}$ : po wykonaniu swoich zadań komisja obwodowa przekazuje posiadane dokumenty jako depozyt kapitanowi (§ 2 ust. 1); zaś po upływie 30 dni od podjęcia przez SN uchwały o ważności referendum komisarz wyborczy nakazuje kapitanowi zniszczenie określonych dokumentów (§ 3 ust. 1).

${ }^{80}$ Dz. U. 2013, poz. 1488.

${ }^{81}$ Dz. U. 2003, nr 102, poz. 951. 
8. Trudno nie zauważyć, że zarówno Kodeks wyborczy i ustawa z 14 maja 2003 roku, jak i stanowione na ich podstawie akty wykonawcze obdarzają sporą liczbą kompetencji kapitana statku morskiego, żadną jednak miarą nie regulując sytuacji, w której nie będzie mógł tych kompetencji wykonywać. Prawodawca zrównuje wyborcze i referendalne prawa i obowiązki z analogicznymi uprawnieniami i zobowiązaniami wójta oraz konsula, nie zauważa jednak specyfiki statusu kapitana, którego z dwoma pozostałymi organami zestawia się zgoła sztucznie i bezrefleksyjnie. Należy założyć wcale prawdopodobną sytuację, w której choćby z powodu choroby, złożony nią na statku bądź przewieziony na ląd kapitan nie będzie w stanie wykonać obowiązków związanych z organizacją wyborów bądź referendum. Prawo wyborcze takiego stanu rzeczy w ogóle nie przewiduje, w odróżnieniu od art. $953 \mathrm{kc}$, nie dopuszczając możliwości realizowania wyborczo-referendalnych kompetencji statku przez jego zastępcę.

Identyfikowanie znanego Kodeksowi morskiemu kapitana $\mathrm{z}$ określonym w Kodeksie cywilnym dowódcą statku nie powinno stwarzać trudności. Z zastępcą kapitana (dowódcy) jest jednak trudniej, czego nie da się powiedzieć o okrętach MW, na których istnieje stanowisko zastępcy dowódcy (pkt 7050 Regulaminu stużby na okrętach marynarki wojennej, wprowadzonego do użytku decyzją nr 242/MON Ministra Obrony Narodowej z 21 czerwca 2011 r ${ }^{82}$ ). Artykuł 59 ustawy z 28 kwietnia 1952 roku o pracy na polskich morskich statkach handlowych w żegludze międzynarodowej ${ }^{83}$ stanowił pierwotnie, że kapitan posiada trzech zastępców, przy czym I zastępcą był oficer kulturalno-oświatowy [zob. Łopuski 1956: 111]. Ustawą z 5 listopada 1958 roku o zmianie ustawy o pracy na morskich statkach handlowych w żegludze międzynarodowej $^{84}$ zredukowano liczbę zastępców do jednego, nadając art. 59 brzmienie: „Zastępcą kapitana jest starszy oficer służby nawigacyjnej”. W obecnym stanie prawnym ani ustawa z 5 sierpnia 2015 roku, ani rozporządzenie Ministra Transportu, Budownictwa i Gospodarki Morskiej z 7 sierpnia 2013 roku w sprawie wyszkolenia i kwalifikacji członków załóg statków morskich ${ }^{85}$ nie stanowią expressis verbis o istnieniu stanowiska służbowego zastępcy (zastępców) kapitana: ustawa odnosi się do kierowników działów (art. 47 ust. 6), jeśli chodzi zaś o żeglugę międzynarodową, rozporządzenie ustala stanowiska - w dziale pokładowym starszego oficera ( $§ 26$ pkt 2 lit. a) oraz w dziale maszynowym w specjalności mechanicznej starszego oficera mechanika ( $\$ 44$ ust. 1 pkt 2 lit. b). Skoro ustawa z 28 kwietnia 1952 roku nie obowiązuje, dla ustalenia,

\footnotetext{
${ }^{82}$ Dz. Urz. MON 2011, nr 13, poz. 191.

83 Dz. U. 1952, nr 25, poz. 171 ze zm.

${ }^{84}$ Dz. U. 1958, nr 68, poz. 338.

${ }^{85}$ Dz. U. 2017, poz. 167.
} 
kto jest zastępcą kapitana statku, należy oprzeć się na następujących źródłach: po pierwsze, na art. 36 ust. 3 ustawy z 5 sierpnia 2015 roku nakazującym dokonywanie na liście załogi ${ }^{86}$ wpisów dotyczących stanowiska zajmowanego na statku ${ }^{87}$, po drugie, na regulaminie ustanawiającym na danym statku stanowisko zastępcy kapitana (jak np. na STS „Fryderyk Chopin”88 czy STS „Pogoria" ${ }^{89}$ ), po trzecie wreszcie, na zdrowym rozsądku i zwyczajach morskich ${ }^{90}$, w których od lat mieszczą się określenia: chief pokładu i chief maszyny.

Nie mogę oprzeć się wrażeniu, że stanowiąc Kodeks wyborczy i ustawę z 14 marca 2003 roku oraz ich akty wykonawcze prawodawca bezrefleksyjnie i mechanicznie obarczył kapitana statku kompetencjami przeznaczonymi dla konsula. Kapitan, i owszem, ,sprawuje kierownictwo statku” (art. $53 \S 1$ $\mathrm{km}$ ) oraz „kieruje pracą na statku” (art. 38 ust. 1 ustawy z 5 sierpnia 2015 r.), konsul kieruje zaś konsulatem generalnym, konsulatem, wicekonsulatem lub agencją konsularną (art. 29 ust. 5a ustawy z 27 lipca 2001 r. o służbie zagranicznej ${ }^{91}$ ). Różnica jest zasadnicza: jak już wspomniałem, aparat pomocniczy konsula sprawuje konsulat bądź inna placówka spośród wskazanych w poprzednim zdaniu in fine, podczas gdy aparat pomocniczy kapitana statku nie istnieje - kapitana portu wspiera kapitanat portu, zaś kapitanat statku nie istnieje. Wedle art. 12 ust. 1 ustawy z 25 czerwca 2015 roku - Prawo konsularne $^{92}$ konsula powołuje i odwołuje minister właściwy do spraw zagranicznych, podczas gdy kapitana statku - armator, którego kapitan ów jest pełnomocnikiem [por. Radwański 2008a: 38-39]. Konsul jest osobą urzędową, zaś kapitan statku osobą taką bywa - czy to w kontekście wyborów (referendum), czy np. asystowania przy składaniu testamentu morskiego. Kompetencji, sit venia verbo, wyborczych kapitan nie może subdelegować nikomu (niezależnie od tego, czy sygnalizowane wyżej stanowisko zastępcy kapitana jest na statku wyodrębnione), konsul zaś może jak najbardziej upoważnić podległych mu urzędników konsularnych do wykonywania funkcji konsularnych w jego imieniu (art. 16 ust. 2 ustawy z 25 czerwca 2015 r. - Prawo konsularne).

${ }^{86} \mathrm{~W}$ odniesieniu do poprzedniego stanu prawnego wspominają o niej też J. Młynarczyk [2002; 118] czy M. Drogosiewicz, J. Nowakowski [2000: 47].

${ }^{87}$ Wzór takiej listy stanowi załącznik do rozporządzenia Ministra Gospodarki Morskiej i Żeglugi Śródlądowej z 5 lipca 2016 r. w sprawie listy załogi statku (Dz. U. 2016, poz. 1016).

${ }^{88} \mathrm{~W}$ pkt 2.4 regulaminu pokładowego tego statku postanowiono wprost, że zastępcą kapitana jest pierwszy oficer (www.fryderykchopin.pl/regulamin-pokladowy.t22/).

${ }^{89} \mathrm{~W}$ rozdziale 2.2 podrozdziale B pkt 1 regulaminu tego statku postanowiono expressis verbis, że zastępcą kapitana jest kapitan-stażysta (www.pogoria.pl/pl/content/regulamin-sts-pogoria).

${ }_{90}$ Do tych zwyczajów odnosi się Radwański [2008a: 39], który zarówno twierdzi, że zastępstwo sprawuje starszy oficer lub najstarszy stopniem oficer nawigacyjny, jak i podnosi problem podstawy, tudzież zakresu osiągania przezeń statusu kapitana statku.

${ }^{91}$ Dz. U. 2017, poz. 161.

92 Dz. U. 2015, poz. 1274 ze zm. 
Prawidło I/1 pkt 1 ppkt 6 załącznika do Międzynarodowej Konwencji o wymaganiach w zakresie wyszkolenia marynarzy, wydawania im świadectw oraz pełnienia wacht, 1978, sporządzonej w Londynie 7 lipca 1978 roku $^{93}$ wcale nie ułatwia odpowiedzi na pytanie o możliwość istnienia na statku stanowiska zastępcy kapitana [odmiennie Puchalski 1989: 7 i n.], odnosi się bowiem do jego doraźnego zastępstwa sede plena (,w razie niezdolności kapitana do pracy”), nie zaś do potencjalnego zastępowania go permanentnie, na co dzień. Jeżeli spełniony zostanie postulat usunięcia z Kodeksu cywilnego testamentu morskiego [wspomina o nim Rudnicki 2015: 85], stanowisko zastępcy kapitana straci swoje kodeksowe umocowanie. Kapitan statku, będący (vide supra) tylko i aż pełnomocnikiem armatora, nie jest organem administracji publicznejej, a odniesień do jego specyficznego niepublicznego statusu prawnego w Kodeksie wyborczym brak. Nie sposób też odpowiedzieć jednoznacznie na pytanie, czy ewentualne błędy kapitana popełnione przy organizacji wyborów (referendum) miałyby wpływ na odwołanie go przez armatora, jeśli jest dobrym nawigatorem, organizatorem, kierownikiem jednostki i załogi, opiekunem ładunku. Pamiętać należy jednak o tym, że chociaż kapitan statku nie jest organem państwa, z racji powierzenia mu przez to państwo pewnych funkcji w zakresie prawa karnego przyznana jest mu ochrona właściwa osobom pełniącym funkcję publiczną w rozumieniu art. $115 \S 19 \mathrm{kk}$ in fine [Woźniewski 2013: 290].

O niezrozumieniu bądź nieznajomości specyfiki statku morskiego świadczy też konstrukcja art. 156 kw. Przez wzgląd na konstytucyjną zasadę równości zgadzam się z tym, że pomieszczenia przeznaczone na siedziby organów wyborczych powinny być łatwo dostępne dla osób niepełnosprawnych (§ 3), nie mogę jednak pojać, dlaczego $\S 5$ nakazuje odpowiednio stosować przepis $\S 3$ do kapitanów statków morskich. Najwyraźniej ustawodawcy zabrakło wyobraźni, a może elementarnej wiedzy z zakresu przestrzennej struktury statków, skoro obarczył ich kapitanów niewykonalnym obowiązkiem. Oczywiście, że pojęcia niepełnosprawności, jej stopnia i zakresu są pojęciowo bardzo szerokie, gdyby jednak wziąć pod uwagę osoby niepełnosprawne ruchowo, ich potencjalny udział w wyborach na statku może być mocno utrudniony. Pamiętać należy jednak i o tym, że niepełnosprawni ruchowo pasażerowie polskich statków morskich płynący nimi w dniu wyborów należą do rzadkości, zaś niepełnosprawnych ruchowo członków załóg w praktyce nie ma. Poza wszystkim zastanawia mnie, dlaczego kapitan statku ma dostosowywać lokalizację siedziby komisji obwodowej (czyli $100 \%$ komisji obwodowych usytuowanych na statku) dla potrzeb niepełnosprawnych, skoro art. $186 \S 1 \mathrm{kw}$ nakazuje wójtom udostępnienie dla tychże osób nie 100 , lecz co najmniej 50\% lokali obwodowych komisji wyborczych.

${ }^{93}$ Dz. U. 1984, nr 39, poz. 201 ze zm.

${ }^{94}$ Skądinąd podobnie jak kapitan portu [odmiennie Godecki 2015: 154 i n.], choć ten - co oczywiste $-\mathrm{z}$ innych przyczyn. 
9. Nie można $\mathrm{w}$ tym kontekście pominąć najistotniejszych zmian, jakie w zakresie wyborów na statkach morskich wprowadziła $\mathrm{z}$ początkiem roku 2016 przywołana już ustawa z 25 czerwca 2015 roku $^{95}$ Projekt ustawy ${ }^{96}$ wniesiony przez prezydenta do marszałka Sejmu 8 stycznia 2015 roku $^{97}$ nie zakładał zmian w art. $15 \mathrm{kw}^{98}$. 6 lutego 2015 roku Sejm skierował projekt do Komisji Nadzwyczajnej do spraw zmian w kodyfikacjach w celu rozpatrzenia ${ }^{99}$, po czym 18 lutego i 22 kwietnia 2015 roku, komisja uczyniła to. Zważywszy na fakt, iż w przedłożonym 10 kwietniu 2015 roku sprawozdaniu podkomisji stałej do spraw nowelizacji Kodeksu wyborczego po raz pierwszy (choć w niewielkim zakresie) odniesiono się do nowelizacji art. $15^{100}$, Komisja nadzwyczajna 22 kwietnia 2015 roku przedłożyła Sejmowi sprawozdanie o projekcie ${ }^{101}$ : znalazło się w nim proponowane nowe brzmienie art. $15 \S 1$ i $2 \mathrm{kw}$ w obecnym kształcie. Jako że 13 maja 2015 roku Sejm skierował projekt ponownie do komisji nadzwyczajnej celem rozpatrzenia poprawek zgłoszonych w II czytaniu ${ }^{102}$, już nazajutrz odrzuciła ona wniesioną w imieniu Klubu Parlamentarnego PiS poprawkę polegającą na skreśleniu nowego brzmienia art. 15, przyjmując za to poprawkę Klubu Parlamentarnego PO zmierzającą do nadania temu artykułowi brzmienia obecnie obowiązującego, łącznie z $\S 3$ i 4; dokumentuje to dodatkowe sprawozdanie komisji ${ }^{103}$. Kolejne etapy procedury legislacyjnej (łącznie z senackim) nie wprowadziły już do art. $15 \mathrm{kw}$ żadnych zmian. Paragraf 2 tego artykułu zasługuje na szczególną uwagę: w pierwotnym brzmieniu Kodeksu wyborczego stanowił on, iż w rozumieniu tego kodeksu „polskim statkiem morskim jest statek będący w całości własnością polskiego armatora mającego siedzibę w Rzeczypospolitej Polskiej, podnoszący polską banderę i dowodzony przez polskiego kapitana".

W toku postępowania ustawodawczego nad projektem zmian w Kodeksie wyborczym pojawily się ze strony Ministerstwa Infrastruktury i Rozwoju uwagi

${ }^{95}$ Pod pojęciem ustawy z 25 czerwca 2015 r. rozumiem ustawę o zmianie ustawy - Kodeks wyborczy, nie zaś opatrzoną tą samą datą ustawę - Prawo konsularne.

${ }^{96}$ Sejm RP. VII kadencja. Druk nr 3084.

${ }^{97}$ Pismo prezydenta RP B. Komorowskiego do marszałka Sejmu R. Sikorskiego z 8 stycznia $2015 \mathrm{r}$.

98 Planowano w nim natomiast (art. $41 \S 5$ in spe) zwolnienie wyborów na statkach morskich od obowiązku używania do tego celu urn o ścianach z przezroczystego materiału.

99 Sprawozdanie stenograficzne z 86. posiedzenia Sejmu Rzeczypospolitej Polskiej w dniu 6 lutego 2015 r. (trzeci dzień obrad), Warszawa 2015, s. 245.

100 Sprawozdanie Podkomisji stałej do spraw nowelizacji Kodeksu wyborczego z 10 kwietnia $2015 \mathrm{r}$.

101 Sejm RP. VII kadencja. Druk nr 3348.

102 Sprawozdanie stenograficzne z 92. posiedzenia Sejmu Rzeczypospolitej Polskiej w dniu 13 maja 2015 r. (pierwszy dzień obrad), Warszawa 2015, s. 23.

${ }^{103}$ Sejm RP. VII kadencja. Druk nr 3348-A. 
dotyczące definicji polskiego statku morskiego: podsekretarz stanu w MIiR zasadnie twierdził: ,[s]pecyficzna dla prawa morskiego instytucja armatora ukształtowała się ze względu na fakt, że morskie statki handlowe eksploatowane są zazwyczaj przez podmioty niebędące ich właścicielami”, eksploatacja taka zatem „odbywa się zwykle na podstawie umowy czarteru, na bazie której armator uzyskuje prawo uprawiania żeglugi cudzym statkiem we własnym imieniu"104. W ślad za tym na forum komisji nadzwyczajnej zdecydowano o skreśleniu z tekstu kodeksu obowiązujących dotąd obostrzeń tyczących się „polskości” armatora ${ }^{105}$. Uczyniono to jak najsłuszniej, po pierwsze dlatego, że sformułowanie o stanowieniu przez statek własności armatora stawiało między pojęciami ,armator” i ,właściciel” znak równości (a przecież nie są to terminy tożsame [por. Młynarczyk 2002: 106-108, 1998: 23-28; Drogosiewicz, Nowakowski 2000: 33-34]), po drugie zaś dlatego, że arbitralne nakazywanie polskiemu armatorowi bycia właścicielem statku w całości - statku będącego przecież rzeczą złożoną! - ignorowało kwestie tak istotne jak części składowe i przynależności tego statku [por. Młynarczyk 2002: 81], choćby na barkowcach często trudne do rozróżnienia [por. Kruczalak-Jankowska 2014: 188], ale przecież również przedmioty połączone z rzeczą tylko dla przemijającego użytku, czy last but not least przewożony na statku ładunek. W świetle art. 51 $\S 2$ kc przynależności należą do właściciela statku jako rzeczy głównej, a przecież w szczególnych sytuacjach kapitan może na podstawie art. $69 \mathrm{~km}$ sprzedać zbędne przynależności, zbędną część żywności (§ 2), czy część ładunku (§ 3). W myśl art. $79 \S 1 \mathrm{~km}$ hipoteka morska obciąża i statek i jego przynależności [por. Adamczak 2005: 245], jak się jednak przyjmuje - stanowiące jego wyposażenie, ale już nie wspomniane wyżej, ulegające zużyciu w toku eksploatacji (jak paliwo czy żywność), tudzież - żadną miarą - ładunek [por. Czaplińska 2005: 1048].

Nietrafne jest $\mathrm{w}$ moim przekonaniu narzucenie przebywającym w morzu wyborcom głosowania na kandydatów zarejestrowanych w okręgu wyborczym właściwym nie dla siedziby armatora, lecz dla obszaru m. st. Warszawy. W ślad za Stanisławem Gebethnerem, krytykującym analogiczne unormowania tyczące się głosów oddawanych za granicą, uważam to za „błędną zasadę” [Gebethner 2007: 81]. Jeszcze większym błędem była zawarta w ordynacji wyborczej z 1991 roku z wyborów na statkach, jednakże próba naprawienia tego lapsusu,

${ }^{104}$ Pismo podsekretarza stanu w MIiR dr hab. D. Pyć do przewodniczącego Komisji Nadzwyczajnej do Spraw Zmian w Kodyfikacjach Sejmu RP W. Pahla z 18 lutego 2015 r., DTM-VI0210-2-AM/15 NK:44807/15.

${ }^{105}$ Sejm RP. VII kadencja. Pełny zapis przebiegu posiedzenia Komisji Nadzwyczajnej do spraw zmian w kodyfikacjach (nr 91) z dnia 22 kwietnia 2015 r., s. 4, 22. Opracowanie nowej definicji polskiego statku morskiego znalazło także odzwierciedlenie na forum plenarnym izby (sprawozdanie stenograficzne z 92. posiedzenia Sejmu: 13). 
dokonana ordynacją z roku 1993, udała się jedynie połowicznie, gdyż (podobnie jak w nowelizacji Kodeksu wyborczego z 25 czerwca 2015 r.) w przeciwieństwie do uregulowań obowiązujących w latach 1954-1991 sztucznie, mechanicznie i bezrefleksyjnie powiązano załogi i pasażerów statków z odległym okręgiem stołecznym. Tak w wyborach prezydenckich, jak i w referendum ogólnokrajowym problem ten nie ma znaczenia [por. Skotnicki 2000: 191], jest to jednak rażąco niesłuszne w wyborach parlamentarnych. Z punktu widzenia prawa wyborczego co najmniej drugorzędne znaczenie ma zestawianie wyników wyborów i referendów na statkach z wynikami uzyskanymi we wszystkich obwodach wyborczych, czy choćby obwodach utworzonych w miastach portowych [zob. np. Wojtaszak 2007: 147-166], jakkolwiek analogię z wyborami w obwodach nadmorskich można interpretować jako jeden $\mathrm{z}$ argumentów za powrotem do powiązania obwodów na statkach z okręgami właściwymi dla siedzib ich armatorów.

10. W zakresie wyborów i referendów na morzu godna uwagi i komentarza jest opiniodawcza działalność Państwowej Komisji Wyborczej. Zacznę od udziału PKW w stanowieniu przez ministra właściwego do spraw gospodarki morskiej aktów prawnych w sprawie utworzenia na statkach obwodów głosowania. Przed wyborami prezydenckimi PKW poinformowała MIiR, że nie zgłasza uwag do projektu rozporządzenia ministra z 24 kwietnia 2015 roku, zwróciła jednak uwagę, że skoro zgodnie z art. $15 \S 3 \mathrm{kw}$ minister tworzy obwody po zasięgnięciu opinii PKW, komisja ta opiniuje projekt rozporządzenia, którym tworzone są konkretne, wymierzone w załączniku doń obwody, zwróciła się przeto z prośbą o przedłożenie nowego projektu zawierającego informacje o owych obwodach ${ }^{106}$. Ta łagodna reprymenda najwyraźniej poskutkowała, gdyż PKW wkrótce powiadomiła MIiR, iż żadnych już uwag do projektu rozporządzenia nie zgłasza ${ }^{107}$. Przed wyborami parlamentarnymi PKW bez zastrzeżeń odniosła się do projektu rozporządzenia ministra z 16 października 2015 roku $^{108}$, jeśli chodzi zaś o referendum ogólnokrajowe i projekt rozporządzenia z 28 sierpnia 2015 roku, PKW nie zgłosiła, i owszem, uwag do jego projektu, wyraziła jednak pogląd, ,że bardziej czytelny byłby” inny jego tytuł i uczyniła to skutecznie ${ }^{109}$.

106 Pismo przewodniczącego PKW W. Hermelińskiego do podsekretarza stanu w MIiR dr hab. D. Pyć z 3 marca 2015 r., ZPOW-600-2/15.

${ }^{107}$ Pismo zastępcy przewodniczącego PKW W. Kozielewicza do podsekretarza stanu w MIiR dr hab. D. Pyć z 14 kwietnia 2015 r., ZPOW-600-2/15.

108 Pismo przewodniczącego PKW W. Hermelińskiego do podsekretarza stanu w MIiR dr hab. D. Pyć z 7 października 2015 r., ZPOW-500-3/15.

109 Pismo zastępcy przewodniczącego PKW W. Kozielewicza do podsekretarza stanu w MIiR dr hab. D. Pyć z 12 sierpnia 2015 r., ZPOW-800-9/15. 
Zainteresowanie PKW budzi kwestia spisu wyborców dla obwodów głosowania utworzonych na statkach. Komisja konsultowała projekt rozporządzenia Ministra Infrastruktury i Rozwoju z 21 kwietnia 2015 roku: początkowo wniosła do niego uwagi tyczące się alternatywnego legitymowania się wyborcy numerami bądź to PESEL, bądź też ważnego polskiego paszportu, oraz sugerowała określenie sposobu zabezpieczenia zaświadczeń w przypadku braku możliwości skorzystania przez kapitana ze znaku holograficznego, np. w przypadku, gdy statek wypłynął przed zarządzeniem wyborów i kapitan znaków takich nie otrzymał ${ }^{110}$. Ostatecznie PKW nie zgłosiła uwag do projektu, który stał się podstawą obowiązującego obecnie aktu ${ }^{111}$. Wkrótce później na mocy art. 1 pkt 3 ustawy z 25 czerwca 2015 roku zmieniono brzmienie art. $34 \S 4$ kw, w związku z czym zaistniała potrzeba wydania przez ministra właściwego do spraw gospodarki morskiej nowego rozporządzenia w przedmiotowej sprawie. Projekt okazał się wyjątkowo nieudany i nieudolny, przewidywał bowiem odbywanie na statkach również wyborów samorządowych i wyborów uzupełniających do senatu, na co PKW rychło zwróciła uwagę ${ }^{112}$. Minister infrastruktury i rozwoju przesłał do PKW poprawiony projekt ${ }^{113}$, w odpowiedzi na co PKW wniosła doń kolejne uwagi, w tym dotyczące zastąpienia „oczywistego błędu” w $\S 10$ ust. 1 pkt 2 i ust. 2 pkt 2 „oczywistą omyłką""114. Przejęcie procesu legislacyjnego przez ministra gospodarki morskiej i żeglugi śródlądowej w żadnym razie nie wpłynęło na nadanie mu tempa: minister i ministerstwo absorbują PKW korespondencją (także w związku z uzgodnieniami międzyresortowymi $)^{115}$, w odpowiedzi na co komisja opiniuje produkt ich pracy ${ }^{116}$.

${ }_{110}$ Pismo przewodniczącego PKW W. Hermelińskiego do podsekretarza stanu w MIiR dr hab. D. Pyć z 19 stycznia 2015 r., ZPOW-430-1/15.

111 Pismo przewodniczącego PKW W. Hermelińskiego do podsekretarza stanu w MIiR dr hab. D. Pyć z 26 lutego 2015 r., ZPOW-430-1/15.

112 Pismo zastępcy przewodniczącego PKW W. Kozielewicza do podsekretarza stanu w MIiR dr hab. D. Pyć z 20 października 2015 r., ZPOW-430-1/15.

113 Pismo ministra infrastruktury i rozwoju (z up. podsekretarz stanu dr hab. D. Pyć) do przewodniczącego PKW W. Hermelińskiego z 5 listopada 2015 r., DTM.VI.0210.8.8.2015.AM NK:303232/15.

114 Pismo sekretarza PKW Beaty Tokaj do podsekretarza stanu w MIiR dr hab. D. Pyć z 16 listopada 2015 r., ZPOW-430-1/15.

115 Pisma do przewodniczącego PKW W. Hermelińskiego - Ministra Gospodarki Morskiej i Żeglugi Śródlądowej (wz. podsekretarz stanu dr K. Kozłowski) z 4 grudnia 2015 r., DTM. VI.0210.8.13.2015.AM NK:329777/15; podsekretarza stanu w MGMiŻŚ Pawła Brzezickiego z 30 grudnia 2015 r., DTM.VI.0210.8.15.2015.AM NK:351060/15 i z 15 stycznia 2016 r., DTM. VI.0210.8.16.2015.AM NK:398/2016.

116 Pisma sekretarza PKW B. Tokaj - do podsekretarza stanu w MGMiŻŚ dr. K. Kozłowskiego z 11 grudnia 2015 r., ZPOW-430-1/15 oraz do podsekretarza stanu w MGMiŻŚ P. Brzezickiego z 7 stycznia 2016 r., ZPOW-430-1/15, z 22 stycznia 2016 r. (w oryginale błędnie 2015), ZPOW-430-1/15 oraz z 3 stycznia 2017 r., ZPOW-430-1/15/16. 
Ponadto, minister cyfryzacji uznał projekt za uzgodniony z nim ${ }^{117}$, zaś w odpowiedzi na złożenie projektu do rozpatrzenia przez komisję prawniczą ${ }^{118}$ Rządowe Centrum Legislacji powiadomiło MGMiŻŚS, że pod warunkiem uwzględnienia poprawek redakcyjnych i uzyskania opinii ministra spraw zagranicznych w sprawie zgodności projektu z prawem Unii Europejskiej projekt nie wymaga rozpatrzenia przez tę komisję ${ }^{119}$. Tak rażąca przewlekłość w postępowaniu prawodawczym świadczy moim zdaniem o tym, że jeśli minister właściwy do spraw gospodarki morskiej nie staje w obliczu zbliżających się raptownie wyborów (referendum), raczy żadną miarą nie przyspieszać prac legislacyjnych, oczekując prawdopodobnie na rok wyborczy (referendalny), w którym zmusi go do tego nagłość rychłego głosowania.

Zdarza się jednak, że w obliczu zbliżających się, czy to wyborów, czy referendum minister właściwy do spraw gospodarki morskiej jest w stanie znacznie przyspieszyć prace legislacyjne. Przykładem tego rodzaju akceleracji jest nowelizacja rozporządzenia Ministra Infrastruktury z 30 kwietnia 2003 roku: jakkolwiek jeszcze 14 lipca 2015 roku minister administracji i cyfryzacji wypowiedział się na temat zaistniałych po stronie MIiR trudności ze zmianą tego aktu przed referendum zarządzonym na 6 września 2015 roku $^{120}$, już 5 sierpnia 2015 roku minister infrastruktury i rozwoju wydał rozporządzenie nowelizujące ${ }^{121}$. Zdaje się, że przypuszczenie wyrażone przeze mnie w poprzednim przykładzie in fine jednak się potwierdza, wątpię wszak, czy należy się z tego powodu cieszyć.

11. Wspominałem wyżej o przypadku odstąpienia od przeprowadzenia na MS „Budowlany” głosowania w wyborach prezydenckich wskutek spadku liczby wyborców poniżej ustawowego minimum. Specyfika statku inspiruje mnie ponadto do rozważenia i innych, całkiem realnych sytuacji, w których

${ }_{117}$ Pismo ministra cyfryzacji (z up. sekretarz stanu M. Zagórski) do podsekretarza stanu w MGMiŻŚ P. Brzezickiego z 5 stycznia 2017 r., DP-WLII.0210.811.2016.

118 Pismo dyrektora Departamentu Prawnego MGMiŻŚ dr. B. Szczurowskiego do dyrektora Departamentu Prawa Gospodarczego Rządowego Centrum Legislacji M. Salamończyk z 9 lutego 2017 r., DP.022.662.2016.BS.

119 Pismo dyrektora Departamentu Prawa Pracy, Rodziny i Infrastruktury RCL A. Juszczyk do dyrektora DP MGMiŻŚS dr. B. Szczurowskiego z 20 lutego 2017 r., RCL.DPŚI.555.230/2015.

${ }_{120}$ Pismo ministra administracji i cyfryzacji (z up. sekretarz stanu mgr S. Huskowski) do ministra infrastruktury i rozwoju mgr M. Wasiak, ministra spraw wewnętrznych mgr T. Piotrowskiej, ministra spraw zagranicznych mgr. G. Schetyny, prezesa Rządowego Centrum Legislacji mgr. M. Berka i generalnego inspektora ochrony danych osobowych dr E. Bielak-Jomaa z 14 lipca 2015 r., DP-WL.0211.50.2015.

${ }^{121}$ Rozporządzenie Ministra Infrastruktury i Rozwoju z 5 sierpnia 2015 r. zmieniające rozporządzenie w sprawie sposobu sporządzania i aktualizacji spisu osób uprawnionych do udziału w referendum ogólnokrajowym dla obwodów głosowania utworzonych na polskich statkach morskich (Dz. U. 2015, poz. 1157). 
głosowanie na danej jednostce może bądź to nie dojść do skutku, bądź też doznać poważnych utrudnień. Zdając sobie sprawę z rangi wyborów i referendum nie można zapominać o tym, że ich organizacja na statku nie tylko nie stanowi podstawowego obowiązku dowodzonej przez kapitana jednostki ale może wywrzeć negatywny wpływ na realizację obowiązków rzeczywiście podstawowych, takich jak prowadzenie prawidłowej nawigacji czy sprawowanie pieczy nad przewożonym ładunkiem. Nie można wykluczyć zaistnienia czasowej zbieżności między dniem głosowania (czy szerzej ujmując okresem, w którym obwodowa komisja wyborcza wykonuje nakazane jej prawem czynności), a określonymi zdarzeniami wynikającymi bądź to z planu rejsu bądź też z zaistniałych ad hoc okoliczności. Gwoli przykładu, kapitan obowiązany jest osobiście prowadzić statek przy wchodzeniu do portów, kanałów i rzek, wychodzeniu z nich oraz w obrębie portów, jak również w każdym przypadku nasuwającym szczególne trudności lub niebezpieczeństwa (art. $59 \S 1 \mathrm{~km}$ ), w związku z czym w przypadku wystąpienia któregokolwiek z tych stanów faktycznych nie może wykonywać kompetencji przewidzianych dlań w Kodeksie wyborczym i ustawie z 14 marca 2003 roku oraz wydanych na ich podstawie aktów wykonawczych. Z Kodeksu morskiego (art. 53 §) wynika ponadto przywołany już, ciążący na wszystkich osobach znajdujących się na statku obowiązek podporządkowania się zarządzeniom kapitana ${ }^{122}$, wydanym w celu zapewnienia bezpieczeństwa i porządku na statku, gdyby zatem we wskazanym celu, czy to część, czy całość składu obwodowej komisji wyborczej została skierowana przez kapitana do wykonywania określonych czynności ratowniczych, porządkowych itp., głosowanie może zostać przerwane bądź w ogóle nie dojść do skutku. Utwierdza mnie w tym przekonaniu również sięgnięcie do przytoczonych już przepisów ustawy z 5 sierpnia 2015 roku. Po pierwsze, osoby należące do komisji obwodowej, tak jak wszystkie inne zatrudnione na statku, mogą zostać obarczone pracą w godzinach nadliczbowych w przypadku potrzeb eksploatacyjnych statku oraz w przypadku konieczności zapewnienia bezpieczeństwa statku, jego pasażerów lub ładunku, albo w związku $\mathrm{z}$ udzielaniem pomocy innym statkom lub osobom będącym w niebezpieczeństwie na morzu (art. 47 ust. 2). Po drugie, armator może zobowiązać marynarza do pozostawania w gotowości do pracy, jeżeli statek oczekuje na manewry, jeżeli zachodzi konieczność ochrony statku, jego pasażerów, załogi lub ładunku, wreszcie jeżeli wymaga tego organizacja obsługi systemów i urządzeń zauto-

${ }^{122}$ Zwracam uwagę, że zarządzenia stanowią inny rodzaj enuncjacji prawotwórczych kapitana niż wspominane już decyzje, w tym uregulowane w art. $37 \S 1-3 \mathrm{kw}$ czy $\S 3$ uchwały PKW z 6 lipca 2015 r. Stanowienie prawa przez kapitana godne jest odrębnych studiów - także zważywszy na to, że statek pasażerski można potraktować jako zakład administracyjny a kapitańskie akty prawne jako źródła prawa zakładowego, o których szerzej Uziębło, Wierczyński [2010: 447-462]. 
matyzowanych na statku (art. 48 ust. 1). Po trzecie, w razie grożącego statkowi niebezpieczeństwa, w szczególności zatonięcia, rozbicia lub pożaru, albo w razie konieczności niesienia pomocy innemu statkowi lub osobom będącym w niebezpieczeństwie na morzu marynarz jest obowiązany do wykonywania pracy poleconej przez kapitana, do czasu zakończenia akcji ratowniczej (art. 81 ust. 1). Którakolwiek z sytuacji wskazanych w trzech poprzednich zdaniach może zaistnieć w dniu głosowania, czy dniu poprzednim; jeśli tak się stanie, nie mam wątpliwości, że armator i kapitan mogą nakładać wspomniane obowiązki na każdego członka załogi stanowiącego skład komisji wyborczej, nawet kosztem utrudnienia bądź uniemożliwienia głosowania, względy wskazane w przywołanych przepisach ustawy z 5 sierpnia 2015 roku dotyczą bowiem spraw o kardynalnym dla statku znaczeniu, spraw istotniejszych niż głosowanie. Kapitan ma obowiązek podejmować decyzje opierając się na cechach, składających się (obok przepisów prawa) na pojęcie dobrej praktyki morskiej, czyli „zasady najkorzystniejszego w danych warunkach postępowania kapitana podczas niebezpieczeństwa dla ludzi i statku”, eo ipso ,postępowanie zgodne z doświadczeniem i zdrowym rozsądkiem" [Załuski 1974: 164]. Jeżeli głosowanie stanowi zagrożenie dla bezpieczeństwa statku, ludzi i ładunku, bądź jeśli przez wzgląd na ochronę tych dóbr, jego przeprowadzenie jest co najmniej utrudnione, należy bez cienia wątpliwości od głosowania odstąpić. Navigare necesse est, eligere est non necesse. Z nadmiernym obciążeniem kapitana obowiązkami związanymi z głosowaniem sąsiaduje jego spostponowanie w art. 9 $\S 3 \mathrm{kw}$ : stanowi on, iż czynności wyborcze określone kalendarzem wyborczym, skargi, odwołania itp. dokonywane są w godzinach urzędowania sądów, organów wyborczych, urzędów gmin i konsulatów; skoro o kapitanie ani słowa, czy należy przez to rozumieć, że intencją ustawodawcy (tego samego przecież, który ustala wymiar jego czasu pracy) jest zobowiązanie go do całodobowej wyborczej aktywności? I jeszcze jedno: wskazane wyżej dokumenty komisji obwodowej nie są dokumentami statku ${ }^{123}$, a zatem kapitan nie ma obowiązku czuwania nad ich ocaleniem, kiedy jako ostatni opuszcza statek w obliczu zagrażającej mu zagłady (art. $61 \S 2 \mathrm{~km}$ ). Skoro jednak ,podstawowym dokumentem odzwierciedlającym przebieg podróży" jest dziennik okrętowy [zob. Drogosiewicz, Nowakowski 2000: 49] (pokładowy, pokładowo-maszynowy), powinien on bez wątpienia zawierać zasadnicze informacje o przebiegu głosowania. Jako że kapitan ponosi odpowiedzialność za należyte prowadzenie i przechowywanie dzienników ( $\$ 7$ ust. 5 rozporządzenia Ministra Infrastruktury z 18 czerwca 2004 roku w sprawie prowadzenia dzienników statku o polskiej

${ }^{123}$ Nie zaliczają się do żadnej z takich kategorii dokumentów statku jak legitymujące, klasyfikacyjne, bezpieczeństwa, sanitarne, załogowe, pasażerskie, ładunkowe i inne, o których szczegółowo Drogosiewicz, Nowakowski [2000: 38-51]. 
przynależności ${ }^{124}$ ), a w obliczu zagłady opuszcza statek jako ostatni, czuwając w miarę możliwości nad ocaleniem m.in. tychże dzienników (art. $61 \S 2 \mathrm{~km})^{125}$, stanowi to szansę na zachowanie udokumentowanych zapisów dotyczących głosowania do celów co najmniej archiwalnych.

12. W wyborach parlamentarnych w 1993 roku utworzono na statkach morskich 220 obwodów głosowania [zob. J. Buczkowski 1996: 102; Skotnicki 2000: 190], w wyborach prezydenckich w roku 1995 powstało ich 151 [zob. J. Buczkowski 1996: 102; Skotnicki 2000: 190], a wyborach do Sejmu i Senatu w 1997 roku o jeden mniej [zob. Skotnicki 2000: 190]. W wyborach do Sejmu i Senatu w latach 1993 i 1997 do spisów wyborców na statkach wpisano odpowiednio 5165 i 6037 osób, czyli ok. 0,02\% ogólnej liczby wyborców [zob. Dyla 2005: 209]. Już w 2001 roku do spisów tych trafiło jedynie 1400 osób (mniej niż $0,01 \%$ ogółu), zaś odsetek głosów ważnych pochodzących z obwodów utworzonych na statkach spadł z $0,03 \%$ w poprzedniej dekadzie do $0,01 \%$; zaliczano je w poczet głosów oddanych w trzech okręgach wyborczych (nr 11, 20 i 44 według ordynacji z 1993 r., nr 25, 26 i 41 w myśl ordynacji z 2001 r.), jednak w żadnym nie przekroczyły granicy $0,77 \%$ oddanych w okręgu ważnych głosów, eo ipso nie wywarły wpływu na podział mandatów [zob. Dyla 2005: 209-210]. Z kolei, w wyborach parlamentarnych w 2011 roku oddano na statkach morskich już tylko 114 głosów $(0,00065 \%$ ogółu uczestniczących w wyborach), w wyborach do PE w 2014 roku 201 głosów (0,002753\% ogółu), w wyborach prezydenckich w 2015 roku odpowiednio 78 głosów $(0,000524 \%$ ogółu), a w ponownym głosowaniu 98 głosów $(0,000578 \%$ ogółu), w wyborach do Sejmu i Senatu w 2015 roku 166 głosów (0,001064\% ogółu), wreszcie, również w roku 2015, w referendum ogólnokrajowym 186 głosów $(0,007805 \%$ ogółu ${ }^{126}$.

Sprawa kosztów wyborów i referendum odbywanych w ostatnich latach na statkach morskich również nie pozostaje bez znaczenia. W wyborach parlamentarnych w 2011 roku budżet państwa wydatkował na nie 3426 zł (przy czym niemożliwe jest ustalenie kosztów przeprowadzenie głosowania na STS „Fryderyk Chopin” z siedzibą armatora w Warszawie, gdyż wydatki w tym odrębnym obwodzie stołecznego okręgu nie były wyodrębniane), w wyborach do PE w 2014 roku 10485 zł, w wyborach prezydenckich w 2015 roku 7790

${ }^{124}$ Dz. U. 2004, nr 162, poz. 1696 ze zm.

${ }^{125} \mathrm{~W}$ art. $64 \S 2$ i art. $71 \S 1 \mathrm{~km}$ funkcjonuje określenie „dziennik okrętowy”, jakkolwiek w wydanym na podstawie art. $52 \mathrm{~km}$ rozporządzeniu Ministra Infrastruktury z 18 czerwca $2004 \mathrm{r}$. mowa o dzienniku pokładowym (§ 4 ust. 1 pkt 1), o dzienniku pokładowym prowadzonym w żegludze krajowej przez niektóre statki, w tym wszystkie rybackie ( 4 ust. 2), tudzież o zapisach $\mathrm{w}$ dowolnej formie prowadzonych na statkach bezpokładowych $(\S 4 \mathrm{a})$.

${ }^{126}$ Pismo szefa Krajowego Biura Wyborczego B. Tokaj do autora z 28 grudnia 2016 r., ZPOW-066-254/16. 
zł (w tym ponowne głosowanie), w wyborach do Sejmu i Senatu w 2015 roku 6750 zł a w referendum ogólnokrajowym w 2015 roku 7840 zł. ${ }^{127}$

Przegląd protokołów z głosowań odbywanych w 2015 roku w obwodach utworzonych na polskich statkach morskich ${ }^{128}$ prowadzi mnie do kilku wniosków. Pierwsze najistotniejsze spostrzeżenie dotyczy frekwencji, która w obwodach „morskich” jest nadzwyczaj wysoka nie tylko in se, ale również (czy raczej zwłaszcza) w porównaniu z obwodami „lądowymi”. Wystarczy wskazać, że w wyborach do Sejmu i Senatu osiągnięto we wszystkich obwodach na statkach frekwencję stuprocentową. W referendum maksymalny ten pułap osiągnięto w obwodzie nr 1000, podczas gdy w pozostałych frekwencja wahała się od 55,333\% (obwód nr 1003) do 96,55172\% (obwód nr 1001) i 98,11320\% (obwód nr 1002). Wreszcie w wyborach prezydenckich w pierwszym głosowaniu frekwencję 100\% odnotowano w obu obwodach, zaś w głosowaniu drugim w obwodzie nr 1001 (z frekwencją 97,91666\% obwód nr 1000 minimalnie mu ustąpił). Drugie zauważalne zjawisko to znikoma liczba głosów nieważnych: w wyborach prezydenckich nie wystąpiły one w obwodach nr 1000 (pierwsza tura) i 1001 (tura druga), zaś w wyborach do Senatu w obwodzie nr 1002; zdarzało się, że wystąpiły one w liczbie 1 wobec 63 głosów ważnych (wybory do Sejmu, obwód nr 1004), czy w proporcji 2/81 (referendum, obwód nr 1003), choć np. w wyborach do PE w 2014 roku ich stosunek do głosów ważnych był W niektórych obwodach co najmniej znaczący (7/34 w obwodzie nr 1002, 7/42 w obwodzie nr 1004). Uwagi odnośnie do frekwencji i udziału głosów nieważnych w całości głosów oddanych prowadzić mogą i powinny do dalej idących (i to raczej socjo- bądź politologicznych) wniosków co do wyborczych zachowań załóg, ergo zachowań o charakterze endogennym, inne natomiast, egzogenne źródło ma dostrzegalna dysproporcja między liczbą kart dostarczonych na pokład a liczbą uprawnionych wyborców i liczbą kart wydanych wyborcom. Zdarzają się sytuacje, w których rozbieżność między obu wartościami jest co najmniej znacząca (jak w referendum 200-150-83 w obwodzie nr 1003 i 10053-52 w obwodzie nr 1002, a w wyborach prezydenckich 100-37-37 w obwodzie nr $1001 \mathrm{w}$ pierwszym głosowaniu), bywało jednak i tak, że do danego obwodu docierało tylko tyle kart, ile wynosiła liczba wyborców i ile kart im wydano (jak po 17 w wyborach parlamentarnych w obwodach nr 1001 i 1002).

13. Naruszenie zasady powszechności wyborów odbywanych w obwodach utworzonych na polskich statkach morskich może wynikać, i wynika, z wielu obiektywnych i subiektywnych przesłanek. Struktura ładunków przewożonych drogą morską ewoluuje, wykazując relatywny spadek przewozów masowych [zob. Adrjanowska 1999: 98]. Już to oddziałuje na zmienność struktury

127 Tamże.

128 Krajowe Biuro Wyborcze, Dokumentacja niearchiwalna. 
zatrudnienia na statkach morskich, daleko bardziej jednak liczebność pracujących na nich załóg spada $\mathrm{z}$ tytułu mechanizacji, automatyzacji i komputeryzacji samych statków [zob. Kołodziej, Kołodziej-Durnaś 2012: 28]. Celowo sięgam do starszych źródeł, by wskazać na wyrażone przed ponad 40 laty przekonanie cenionego autora, że jednym z celów automatyzacji jest „dążność do wyeliminowania obsługi przez człowieka, a co za tym idzie do zmniejszenia stanu załóg i wraz z tym kosztów eksploatacyjnych statku" [Piwowoński 1975: 25]. Dość powiedzieć, że pierwszy polski statek z aparaturą w pełni zautomatyzowaną przekazano do użytku 13 września 1966 roku [zob. Zając 1971: 304, 306; Drzemczewski 2009: 69-70, 2012: 48; Adamczyk i in. 2011: 9, 280]: ta wiadomość sprzed ponad półwiecza pozwala uzmysłowić sobie skalę i tempo zmniejszania się składu załóg statków morskich na przestrzeni ostatnich dekad. Skoro również z tej przyczyny dzisiejsza praca na morzu jest „zupełnie inna niż ta sprzed kilkudziesięciu czy nawet dziesięciu lat" [Kołodziej, Kołodziej-Durnaś 2012: 28], należałoby dostosować do tego przepisy prawa wyborczego. Oczywistym wyrazem reakcji legislacji wyborczej na zmiany struktury osobowej statków morskich jest sukcesywne obniżanie minimalnej liczby zaokrętowanych wyborców, której przewidywane osiągnięcie upoważnia czy to armatora (do niedawna), czy kapitana (obecnie) do wniesienia o utworzenie obwodu na statku. Spadek tego minimum o 40\% (z 25 osób, o których mowa w ordynacjach z lat 1954 i 1956, poprzez 20 do 15 osób w obecnym stanie prawnym) jest jednak półśrodkiem, a utrzymanie obecnego progu jedynie maskuje dramatyczny stan floty morskiej podnoszącej polską banderę. Nie porzucając ani na jotę tezy o połowicznym charakterze tego rozwiązania, świadom jego ułomności pozwolę sobie jednak zaproponować obniżenie kodeksowego minimum do 10, zaznaczając zarazem, że jeszcze dalej idące obniżanie tego progu nie tylko mija się z celem, ale spowoduje, że wszyscy wyborcy na statku będą zarazem wchodzić w skład obwodowej komisji wyborczej.

Kiedyś takie czarnowidztwo byłoby hipotetyzowaniem ad absurdum. Gwoli przykładu, w wyborach do Sejmu zarządzonych na 21 marca 1976 roku oddano głosy na 119 statkach Polskich Linii Oceanicznych należących do okręgów wyborczych w Gdańsku i Gdyni, przebywających w tym czasie w podróży lub w portach zagranicznych [zob. „W atmosferze powagi...” 1976a: 1]; analogicznie, głosowania odbywano na 46 statkach rybackich należących do Przedsiębiorstwa Połowów Dalekomorskich i Usług Rybackich „Dalmor” [tamże]. Bokserska reprezentacja Śląska oddała swoje głosy na pokładzie MS „Dęblin" stojącego na redzie irlandzkiego potu Dublin [zob. „Wybory w kraju...” 1976b: 2]. Na statkach PLO utworzono w wyborach do Sejmu 13 października 1985 roku 105 komisji wyborczych, których sprawozdania przekazywano drogą teleksową do zlokalizowanej w siedzibie armatora Obwodowej Komisji Wyborczej nr 81 w Gdyni [zob. „Ci co na morzu...” 1985: 3]. Jak jest dzisiaj, wyżej wspominałem i sięgnąłem do statystyk. 
Krzysztof Skotnicki uznał onegdaj tworzenie obwodów głosowania za granicą „za całkowite nieporozumienie” [Skotnicki 2006: 58], opierając swój argument na malejącej liczbie głosujących w nich wyborców, tudzież rosnących kosztach odbywanych tam wyborów [por. Skotnicki 2006: 58-59]. Co zastanawiające, ale i inspirujące, nie znalazłem u tego autora postulatu rezygnacji z wyborów na morzu. Opowiedział się on natomiast za umożliwieniem wyborcom na statkach głosowania za pośrednictwem poczty bądź przez pełnomocnika [por. Skotnicki 2000: 191]. Wedle Kodeksu wyborczego w obwodach głosowania utworzonych na statkach ani głosowanie korespondencyjne (art. 53a § 4), ani głosowanie przez pełnomocnika (art. 54 § 4) nie jest możliwe. Gdybym miał się poważnie zastanowić nad koncepcją wyartykułowaną przez łódzkiego autora i uzupełnił ją o postulat umożliwienia również „morskim” wyborcom głosowania elektronicznego, jestem przekonany, że spełnienie tych oczekiwań przysłużyłoby się pełniejszej niż obecnie realizacji zasady powszechności w polskim prawie wyborczym. Mam jednak pewne wątpliwości. Pierwsza bierze się z częściowo tylko przewidywalnej przyszłości społeczeństwa informacyjnego, w którym być może jedyną formą każdego głosowania będzie e-voting, w związku z czym moje rozważania nad perspektywami wyborów na statkach całkowicie stracą na aktualności. Druga wątpliwość nie ma charakteru futurystycznego, lecz jest mocno osadzona w smutnej teraźniejszości polskiej żeglugi: z punktu widzenia prawa morskiego najwłaściwsze wydają mi się takie rozwiązania prawa wyborczego, które przyczynią się (pośrednio, rzecz jasna) do powrotu polskich statków pod polską banderę. W pełni opowiadam się za wprowadzeniem do wyborów na statkach alternatywnych metod głosowania, obawiam się jednak, czy osiągnięty tą drogą wzrost liczebności głosujących na morzu nie będzie (w ślad za lobbingiem ze strony rzeczników „tanich bander") poczytywany za wyraz rozwoju polskiej żeglugi morskiej. Fałszywego rozwoju. Najlepszym rozwiązaniem byłoby utrzymanie w zreformowanej postaci wyborów i referendów na statkach, przy jednoczesnym podjęciu przez ustawodawcę zróżnicowanych środków prawnych i ekonomicznych na tyle skutecznych, by polska bandera załopotała na polskich statkach w miejsce bander obcych. Jeśli polska flota nie podniesie się z obecnego tragicznego stanu, nie wiem, czy nie lepiej byłoby całkowicie zrezygnować z wyborów i referendów na morzu. $Z$ pełną świadomością powagi sytuacji, rzecz jasna, w odróżnieniu od irracjonalnego skasowania wyborów parlamentarnych na morzu w 1991 roku

Istnieje jednak jeszcze jeden, już sygnalizowany wyżej, sposób na zwiększenie liczbowego stanu wyborców przebywających na morzu w dniu głosowania. Raz jeszcze przywołam wystąpienie prezesa zarządu, dyrektora naczelnego LOTOS Petrobaltic S.A. do podsekretarza stanu w MIiR z 9 stycznia 2015 roku W ślad za postulatem zawartym w tym piśmie Ministerstwo Infrastruktury 
i Rozwoju usiłowało bezskutecznie apelować do Komisji Nadzwyczajnej do Spraw Zmian w Kodyfikacjach Sejmu RP o zapewnienie czynnego prawa wyborczego osobom przebywającym $\mathrm{w}$ dniu wyborów na stacjonarnych platformach wiertniczych i wydobywczych posadowionych na dnie morskim na stałe, nie są one bowiem statkami i nie są kierowane przez kapitanów ${ }^{129}$. Niestety, władza ustawodawcza nie uwzględniła ani tej sugestii egzekutywy, ani udostępnionych przez nią alarmujących informacji, że kilkadziesiąt tysięcy polskich marynarzy pływających na statkach podnoszących polską banderę pozbawionych jest prawa głosu, ani propozycji umożliwienia im głosowania drogą elektroniczną ${ }^{130}$. W moim głębokim przekonaniu należy bezsprzecznie znowelizować Kodeks wyborczy także w kierunku umożliwienia odbywania głosowań na takich morskich jednostkach zakładów górniczych jak platformy wiertnicze i wydobywcze posadowione na dnie morskim na stałe. Obecny stan prawny wykracza przeciwko zasadzie powszechności prawa wyborczego. Chodzi nie tylko o sprawiedliwe wyrównanie praw wyborczych załóg platform będących statkami z załogami platform niebędących nimi, ale i o zaakcentowanie faktu, że największą część wyborców głosujących na morzu w wyborach i referendum w 2015 roku stanowiły łącznie osoby zatrudnione na platformach uznanych naówczas za polskie statki morskie.

Zmiany, byle racjonalne, są niezbędne, nie mogę bowiem określić obowiązujących regulacji prawnych tyczących się wyborów i referendów na morzu inaczej niż jako rażąco naruszające zarówno powszechność prawa wyborczego, jak i prawa członków załogi, tudzież pasażerów statku morskiego. Przyczyn tego godnego krytyki stanu rzeczy doszukuję się w dwóch sferach. Pierwszą jest sfera ściśle prawna, a zwłaszcza ograniczenie minimalnej liczby przebywających na statku osób, posiadających czynne prawo wyborcze oraz fakultatywny charakter dyskrecjonalnej siłą rzeczy kompetencji kapitana statku do złożenia wniosku do właściwego ministra ${ }^{131}$. Druga sfera ma charakter tyleż ekonomiczny co polityczny, a rozumiem przez nią drastyczne, wręcz dramatyczne zmniejszenie liczby tych statków morskich, na których można kumulatywnie spełnić wszystkie przesłanki niezbędne do zorganizowania wyborów i referendów, ze szczególnym uwzględnieniem sprowadzenia liczebności statków podnoszących polską banderę do stanu śladowego. Jeśli zmiany w Kodeksie wyborczym ustawą z 25 czerwca 2015 roku tyczące się definicji polskiego statku morskiego i kompetencji jego kapitana do wnoszenia o utworzenie obwodu,

${ }^{129}$ Pismo podsekretarza stanu w MIiR dr hab. D. Pyć do przewodniczącego KNZK Sejmu RP W. Pahla z 18 lutego 2015 r.

130 Tamże.

131 Nie można zapominać i o tym, że utworzenie obwodu na statku jest także fakultatywną kompetencją ministra, skoro korzysta z niej dopiero po zasięgnięciu opinii PKW, skądinąd tak samo niewiążącej, jak i wniosek kapitana statku. 
oceniam względnie pozytywnie, raz jeszcze odniosę się jak najbardziej krytycznie do powiązania głosowań na statkach z okręgiem właściwym dla Warszawy. Próbuję bezskutecznie dociekać przyczyn, dla których dokonano tej zmiany. Nie znajdując ani jednej usprawiedliwiającej ją przesłanki, jak najgłośniej wzywam, by powrócić do status quo ante, czyli ponowne przyporządkować tworzone na statkach obwody do okręgów właściwych dla siedzib ich armatorów. Wniosek de lege ferenda opieram przede wszystkim na argumencie więzi między wyborcą a kandydatem do wybieralnego urzędu; mając na uwadze, że w latach 2019-2020 mają się odbyć wybory do wszystkich godności obsadzanych również przez wyborców „,morskich”, gorąco postuluję, by przywrócenia racjonalnego i sprawdzonego rozwiązania nie odkładać na ostatnią chwilę. W wyborach prezydenckich i referendum ogólnokrajowym (w tym zapowiedzianym, choć bardzo ogólnikowo, przez prezydenta RP na rok 2018) nie ma w istocie znaczenia, której okręgowej komisji wyborczej, lub któremu komisarzowi wyborczemu zostaną przekazane głosy oddane na statkach, bezcelowe jest jednak różnicowanie właściwości organu administracji wyborczej wyższego szczebla (w stosunku do komisji obwodowej na statku) w zależności od tego, jakiego rodzaju głosowanie jest na statku przeprowadzane. Przy niezbędnych zmianach w Kodeksie wyborczym niechaj pozostanie zatem w obecnym brzmieniu art. 26 ust. 2 ustawy z 14 marca 2003 roku, w świetle którego to komisarzowi wyborczemu właściwemu dla siedziby armatora przekazywane są wyniki i protokoły głosowania z obwodów na polskich statkach morskich, i niech odnośne przepisy Kodeksu wyborczego odzyskają podobne brzmienie.

14. „Statek, który wypływa z portu, jest szczególnym zjawiskiem: to dom, który nie jest domem; zakład pracy, do którego nie trzeba dojeżdżać kolejką elektryczną; wolne terytorium, ograniczone nieznośną i upokarzającą ciasnotą" [Ostrołęka 1966: 10; częściowo odmiennie Kołodziej, Kołodziej-Durnaś 2012: 27-43; diametralnie różnie Janiszewski 1987: 153-161]. Do rangi paradoksu urasta fakt, że tak kazuistycznie ujęta w przepisach prawa organizacja odbywanych na statkach morskich wyborów na określone urzędy państwowe i referendum ogólnokrajowego w żadnym zakresie nie konweniuje z powierzeniem załodze prawa dokonywania jakichkolwiek wyborów osób zajmujących na statku stanowiska kierownicze, czy rozstrzyganiem przez nią o ważnych sprawach statku w formie sankcjonowanego prawem referendum. Inny ceniony autor pisał przed 45 laty o, samowładczym a rozpowszechnionym jeszcze dzisiaj stylu dowodzenia załogą statku" [Milian 1972: 232-233]. Trudno nie tylko nie zgodzić się z tym stwierdzeniem, ale i przyznać, że autokratyzm $\mathrm{w}$ dowodzeniem statkiem oraz jego załogą jest zjawiskiem tyleż aktualnym, co pogłębiającym się z wielu przyczyn, zwłaszcza ekonomicznych. $Z$ tego samego 1972 roku pochodzi wyrażone przez innych autorów przekonanie, że „współgospodarzem statku jest załoga" [Koczorowski i in. 1972: 62], dzisiaj niestety nieodpowiadające prawdzie. 
Skoro zatem załoga nie jest współgospodarzem statku, niechaj poczuje się choć w minimalnym stopniu współgospodarzem państwa - zwłaszcza poprzez instytucje wyborów i referendum. Jeśli jednak powrót polskich statków pod polską banderę nie stanie się faktem, perspektywy zasięgu decydowania marynarzy o stanie spraw kraju postrzegam pesymistycznie.

\section{BIBLIOGRAFIA}

Adamczak Wojciech. 2005. „Zastaw na statku morskim według prawa polskiego”. W Polskie prawo prywatne w dobie przemian. Księga jubileuszowa dedykowana Profesorowi Jerzemu Młynarczykowi. Gdańsk: Wydawnictwo Uniwersytetu Gdańskiego.

Adamczyk Krzysztof, Jerzy Drzemczewski, Bohdan Huras. 2011. Polskie Linie Oceaniczne: album floty 1951-2011. Gdynia: Pomorska Oficyna Wydawniczo-Reklamowa Porta Mare.

Adrjanowska Ewa. 1999. „Zasoby i walory morza w przestrzenno-ekonomicznym systemie lądu". W W kręgu cywilizacji europejskiej. Praca ofiarowana Profesorowi Andrzejowi Piskozubowi w 40-lecie pracy naukowej. Toruń: Wydawnictwo Adam Marszałek.

Bogusz Mariusz. 2010. „Problem charakteru prawnego zasad techniki prawodawczej”. Gdańskie Studia Prawnicze XXIV.

Buczkowski Jerzy. 1996. Powszechność wyborów w praktyce III Rzeczypospolitej. Rzeszów: Wydawnictwo Oświatowe FOSZE.

Buczkowski Łukasz. 2011. „Stwierdzenie ważności wyborów parlamentarnych i prezydenckich na gruncie kodeksu wyborczego". W Krzysztof Skotnicki (red.), Kodeks wyborczy. Wstępna ocena.. Warszawa: Wydawnictwo Sejmowe.

Chojecka Ewa. 1995. „Pomnik Poległych Stoczniowców w Gdańsku - uwspółcześniony tropaion”. Gdańskie Studia Muzealne 6.

„Ci co na morzu”. W „W poczuciu odpowiedzialności za Polskę”. 1985. Dziennik Battycki 219.

Czaplińska Magdalena. 2005. „Egzekucja ze statków morskich”. Gdańskie Studia Prawnicze XIV.

Drogosiewicz Maciej, Janusz Nowakowski. 2000. Eksploatacja statku handlowego. Gdynia: Akademia Marynarki Wojennej im. Bohaterów Westerplatte.

Drzemczewski Jerzy. 2009. Na śródziemnomorskim szlaku: 1924-2008. Gdynia: Pomorska Oficyna Wydawniczo-Reklamowa Porta Mare.

Drzemczewski Jerzy. 2012. Polskie Linie Oceaniczne 1951-2012. Zarys działalności. Gdynia: Pomorska Oficyna Wydawniczo-Reklamowa Porta Mare.

Dyla Adam. 2005. „Podział kraju na okręgi wyborcze w wyborach do Sejmu - ewolucja”. W Zbigniew Witkowski (red.), Konstytucjonalizm włoski i polski w aktualnych fazach ich przemian. Materiały z sympozjum. Toruń, 2 czerwca 2005. Torun: Wydawnictwo „Dom Organizatora".

Gebethner Stanisław. 2007. „Głosowanie poza granicami państwa w wyborach do Sejmu i do Senatu, w wyborach do Parlamentu Europejskiego oraz a wyborach prezydenckich i referendum ogólnokrajowym. Doświadczenia i propozycje nowych rozwiązań”. W Sabina Grabowska, Radosław Grabowski (red.), Alternatywne sposoby głosowania a aktywizacja elektoratu. Międzynarodowa Konferencja Naukowa, Rzeszów, 26-27 marca 2007 roku. Rzeszów: Poligrafia Wyższego Seminarium Duchownego.

Godecki Zbigniew. 2015. „Status prawny kapitana portu”. Prawo Morskie XXXI 151-160. 
Janiszewski Ludwik. 1987. „Krytyka Goffmanowskiej koncepcji statku morskiego jako instytucji zamkniętej”. Ruch Prawniczy, Ekonomiczny i Socjologiczny 1.

Koczorowski Eugeniusz, Jerzy Koziarski, Ryszard Pluta. 1972. Zwyczaje i ceremoniat morski. Gdańsk: Wydawnictwo Morskie.

Kołodziej Arkadiusz, Agnieszka Kołodziej-Durnaś. 2012. „Determinanty więzi społecznej na statku - badania jakościowe wśród marynarzy". Opuscula Sociologica 2.

Koziński Mirosław H. 2010. Morskie prawo publiczne. Gdynia: Wydawnictwo Akademii Morskiej.

Kruczalak-Jankowska Joanna. 2014. „Statek morski w postępowaniu upadłościowym”. Gdańskie Studia Prawnicze XXXII.

Łopuski Jan. 1956. Poradnik prawny dla kapitanów i oficerów polskich statków handlowych. Warszawa: Wydawnictwa Komunikacyjne.

Milian Lech. 1972. Czas wolny marynarzy na morskich statkach transportowych. Szczecin: Wydawnictwo Instytutu Zachodniopomorskiego.

Młynarczyk Jerzy. 1998. „Armator jako przedsiębiorca”. Rejent 3.

Młynarczyk Jerzy. 2002. Prawo morskie. Gdańsk: Arche.

Ostrołęka Zygmunt. 1966. Kolory mojego morza. Gdynia: Wydawnictwo Morskie.

Piwowoński Jan. 1975. Nowoczesny statek handlowy. Gdańsk: Wydawnictwo Morskie.

Puchalski Jerzy. 1989. „Zastępca kapitana statku - prawo i praktyka”. Prawo i Orzecznictwo Morskie 13-14.

Radwański Piotr. 2008a. „Pozycja prawna kapitana (2). Przedstawiciel armatora”. Nasze Morze 4.

Radwański Piotr. 2008b. „Pozycja prawna kapitana (7). Publiczno-prawne kompetencje”. Nasze Morze 9.

Rudnicki Jan. 2015. Testament żotnierski i testamenty wojskowe w europejskiej tradycji prawnej. Kraków: OD.NOWA.

Sidor Gabriela. 2014. „Zatrzymanie osoby przez kapitana statku morskiego”. Studia Iuridica Lublinensia 21.

Skotnicki Krzysztof. 2000. Zasada powszechności w prawie wyborczym. Zagadnienia teorii i praktyki. Łódź: Wydawnictwo Uniwersytetu Łódzkiego.

Skotnicki Krzysztof. 2006. [Głos w dyskusji]. W Sabina Grabowska, Radosław Grabowski (red.), Prawo wyborcze do parlamentu w wybranych państwach europejskich. Międzynarodowa Konferencja Naukowa, Rzeszów 3-4 kwietnia 2006 roku. Rzeszów: Poligrafia Wyższego Seminarium Duchownego.

Skotnicki Krzysztof. 2007. Skład obwodowych komisji wyborczych i obwodowych komisji do spraw referendum. W Ferdynand Rymarz (red.), Iudices electionis custodes (Sędziowie kustoszami wyborów). Księga Pamiątkowa Państwowej Komisji Wyborczej. Warszawa: Wydawnictwo Krajowego Biura Wyborczego.

Sokala Andrzej. 2011. „Administracja wyborcza w polskim kodeksie wyborczym”. W Krzysztof Skotnicki, Kodeks wyborczy. Wstępna ocena. Warszawa: Wydawnictwo Sejmowe.

Sokala Andrzej, Mikołaj Święcki. 2007. Administracja wyborcza w III Rzeczypospolitej Polskiej (struktura organizacyjna i charakter prawny). W Ferdynand Rymarz (red.), Iudices electionis custodes (Sędziowie kustoszami wyborów). Księga Pamiątkowa Państwowej Komisji Wyborczej. Warszawa: Wydawnictwo Krajowego Biura Wyborczego.

Uziębło Piotr, Grzegorz Wierczyński. 2010. „Charakter prawny aktów prawa zakładowego”. Gdańskie Studia Prawnicze XXIV.

„W atmosferze powagi i patriotycznej jedności przebiegały wybory w województwach gdańskim i elbląskim. Manifestacyjne poparcie programu dynamicznego rozwoju Polski”. 1976a. Dziennik Baltycki 66. 
Wojtaszak Andrzej. 2007. „Wybory parlamentarne i samorządowe w Świnoujściu na tle przemian politycznych w Polsce w latach 1989-2005”. W S. Mollin (red.), Świnoujście - tradycja i współczesność. Z. 1. Świnoujście: Dom-Inwest, Elmos, Wydawnictwo „Dokument” Oficyna Archiwum Państwowego w Szczecinie.

Woźniewski Krzysztof. 2013. „Publicznoprawne funkcje kapitana statku z art. $72 \S 1$ kodeksu morskiego w sferze prawa karnego procesowego - zarys problematyki”. Gdańskie Studia Prawnicze XXIX.

„Wybory w kraju i za granicą”. 1976b. Dziennik Bałtycki 66.

Zając Edward. 1971. „Wodowanie statku m/s Sanok”. Rocznik Sanocki III.

Załuski Bolesław. 1974. „Socjologiczne aspekty kierowania załogą statku transportowego”. Acta Universitatis Nicolai Copernici. Nauki Humanistyczno-Społeczne. Z. 62. Socjologia II.

Zyzda Barbara. 2015. „Publicznoprawne funkcje kapitana statku morskiego”. W Mirosław Sadowski (red.), Z badań nad prawem, administracja i myśla polityczna. Acta Erasmiana. T. 10. Wrocław: Katedra Historii Doktryn Politycznych i Prawnych Wydziału Prawa, Administracji i Ekonomii Uniwersytetu Wrocławskiego.

\section{AKTY PRAWNE}

Międzynarodowa konwencja w zakresie wyszkolenia marynarzy, wydawania im świadectw oraz pełnienia wacht, 1978, sporządzona w Londynie dnia 7 lipca 1978 r. (Dz. U. 1984, nr 39, poz. 201 ze zm.).

\section{Ustawy}

Ustawa z dnia 28 kwietnia 1952 r. o pracy na polskich morskich statkach handlowych w żegludze międzynarodowej (Dz. U. 1952, nr 25, poz. 171 ze zm.).

Ustawa z dnia 25 września 1954 r. - Ordynacja wyborcza do rad narodowych (Dz. U. 1954, nr 43, poz. 193).

Ustawa z dnia 24 października 1956 r. - Ordynacja wyborcza do Sejmu Polskiej Rzeczypospolitej Ludowej (Dz. U. 1960, nr 58, poz. 325 ze zm.).

Ustawa z dnia 5 listopada $1958 \mathrm{r}$. o zmianie ustawy o pracy na polskich morskich statkach handlowych w żegludze międzynarodowej (Dz. U. 1958, nr 68, poz. 338).

Ustawa z dnia 31 stycznia 1959 r. o cmentarzach i chowaniu zmarłych (Dz. U. 2015, poz. 2126 ze zm.).

Ustawa z dnia 23 kwietnia 1964 r. - Kodeks cywilny (Dz. U. 2017, poz. 459).

Ustawa z dnia 31 stycznia 1980 r. o godle, barwach i hymnie Rzeczypospolitej Polskiej oraz o pieczęciach państwowych (Dz. U. 2016, poz. 625 ze zm.).

Ustawa z dnia 13 lutego 1984 r. - Ordynacja wyborcza do rad narodowych (Dz. U. 1988, nr 7, poz. 55).

Ustawa z dnia 7 kwietnia 1989 r. - Ordynacja wyborcza do Sejmu Polskiej Rzeczypospolitej Ludowej X kadencji, na lata 1989-1993 (Dz. U. 1989, nr 19, poz. 102 ze zm.)

Ustawa z dnia 7 kwietnia 1989 r. - Ordynacja wyborcza do Senatu Polskiej Rzeczypospolitej Ludowej (Dz. U. 1989, nr 19, poz. 103)

Ustawa z dnia 27 września 1990 r. o wyborze Prezydenta Rzeczypospolitej Polskiej (Dz. U. 2010, nr 72, poz. 467 ze zm.).

Ustawa z dnia 10 maja 1991 r. - Ordynacja wyborcza do Senatu Rzeczypospolitej Polskiej (Dz. U. 1994, nr 72, poz. 319 ze zm.).

Ustawa z dnia 28 czerwca 1991 r. - Ordynacja wyborcza do Sejmu Rzeczypospolitej Polskiej (Dz. U. 1991, nr 59, poz. 252).

Ustawa z dnia 28 maja 1993 r. - Ordynacja wyborcza do Sejmu Rzeczypospolitej Polskiej (Dz. U. 1993, nr 45, poz. 205 ze zm.). 
Ustawa z dnia 6 czerwca 1997 r. - Kodeks karny (Dz. U. 2016, poz. 1137 ze zm.).

Ustawa z dnia 27 lipca 2001 r. - O stużbie zagranicznej (Dz. U. 2017, poz. 161).

Ustawa z dnia 18 września 2001 r. - Kodeks morski (Dz. U. 2016, poz. 66).

Ustawa z dnia 14 marca 2003 r. o referendum ogólnokrajowym (Dz. U. 2015, poz. 318).

Ustawa z dnia 23 stycznia 2004 r. - Ordynacja wyborcza do Parlamentu Europejskiego (Dz. U. 2004, nr 25, poz. 219 ze zm.).

Ustawa z dnia 5 stycznia 2011 r. - Kodeks wyborczy (Dz. U. 2017, poz. 15).

Ustawa z dnia 29 czerwca 2011 r. - Prawo geologiczne i górnicze (Dz. U. 2016, poz. 1131 ze zm.).

Ustawa z dnia 25 czerwca 2015 r. o zmianie ustawy - Kodeks wyborczy (Dz. U. 2015, poz. 1043).

Ustawa z dnia 25 czerwca 2015 r. - Prawo konsularne (Dz. U. 2015, poz. 1274 ze zm.)

Ustawa z dnia 5 sierpnia 2015 r. o pracy na morzu (Dz. U. 2015, poz. 1569 ze zm.).

\section{Rozporządzenia}

Rozporządzenie Ministra - Kierownika Urzędu Gospodarki Morskiej z dnia 7 maja 1983 r. w sprawie zasad i warunków sprzedaży, podawania i spożywania napojów alkoholowych na morskich statkach handlowych, w żegludze międzynarodowej oraz w międzynarodowych portach morskich (Dz. U. 1983, nr 25, poz. 121).

Rozporządzenie Prezesa Rady Ministrów z dnia 20 czerwca 2002 r. w sprawie „Zasad techniki prawodawczej" (Dz. U. 2016, poz. 283).

Rozporządzenie Ministra Infrastruktury z dnia 30 kwietnia 2003 r. w sprawie sposobu sporządzania i aktualizacji spisu osób uprawnionych do udziału w referendum ogólnokrajowym dla obwodów głosowania utworzonych na polskich statkach morskich (Dz. U. 2003, nr 74, poz. 669 ze zm.).

Rozporządzenie Ministra Infrastruktury z dnia 30 kwietnia 2003 r. w sprawie szczegółowych wymagań oraz obowiązków kapitana polskiego statku morskiego w zakresie ochrony lokalu obwodowej komisji do spraw referendum w czasie przerwy w głosowaniu (Dz. U. 2003, $\mathrm{nr} 75$, poz. 675).

Rozporządzenie Ministra Kultury z dnia 3 czerwca 2003 r. w sprawie sposobu przekazywania, przechowywania i udostępniania dokumentów z przeprowadzonego referendum ogólnokrajowego (Dz. U. 2003, nr 102, poz. 951).

Rozporządzenie Ministra Infrastruktury z dnia 18 czerwca 2004 r. w sprawie prowadzenia dzienników statku o polskiej przynależności (Dz. U. 2004, nr 162, poz. 1696 ze zm.).

Rozporządzenie Ministra Infrastruktury z dnia 23 lutego 2005 r. w sprawie trybu postępowania kapitana statku wobec osoby podejrzanej o popełnienie przestępstwa przeciwko bezpieczeństwu żeglugi morskiej (Dz. U. 2005, nr 42, poz. 405).

Rozporządzenie Ministra Transportu, Budownictwa i Gospodarki Morskiej z dnia 7 sierpnia 2013 r. w sprawie wyszkolenia i kwalifikacji członków załóg statków morskich (Dz. U. 2017, poz. 167).

Rozporządzenie Ministra Kultury i Dziedzictwa Narodowego z dnia 13 listopada 2013 r. w sprawie sposobu przekazywania, przechowywania i udostępniania dokumentów z wyborów (Dz. U. 2013, poz. 1488).

Rozporządzenie Ministra Gospodarki z dnia 25 czerwca 2014 r. w sprawie szczegółowych wymagań dotyczących prowadzenia ruchu zakładów górniczych wydobywających kopaliny otworami wiertniczymi (Dz. U. 2014, poz. 812).

Rozporządzenie Ministra Infrastruktury i Rozwoju z dnia 21 kwietnia 2015 r. w sprawie szczegółowych wymagań oraz obowiązków kapitana polskiego statku morskiego w zakresie ochrony lokalu wyborczego w czasie przerwy w głosowaniu spowodowanej nadzwyczajnymi wydarzeniami (Dz. U. 2015, poz. 576). 
Rozporządzenie Ministra Infrastruktury i Rozwoju z dnia 21 kwietnia 2015 r. w sprawie spisu wyborców dla obwodów głosowania utworzonych na polskich statkach morskich (Dz. U. 2015, poz. 586).

Rozporządzenie Ministra Infrastruktury i Rozwoju z dnia 24 kwietnia 2015 r. w sprawie utworzenia obwodów głosowania na polskich statkach morskich w wyborach Prezydenta Rzeczypospolitej Polskiej (Dz. U. 2015, poz. 590).

Rozporządzenie Ministra Infrastruktury i Rozwoju z dnia 5 sierpnia 2015 r. zmieniające rozporządzenie w sprawie sposobu sporządzania i aktualizacji spisu osób uprawnionych do udziału w referendum ogólnokrajowym dla obwodów głosowania utworzonych na polskich statkach morskich (Dz. U. 2015, poz. 1157).

Rozporządzenie Ministra Infrastruktury i Rozwoju z dnia 28 sierpnia 2015 r. w sprawie utworzenia obwodów głosowania dla wyborców przebywających na polskich statkach morskich w referendum ogólnokrajowym wyznaczonym na dzień 6 września 2015 r. (Dz. U. 2015, poz. 1287).

Rozporządzenie Ministra Infrastruktury i Rozwoju z dnia 16 października 2015 r. w sprawie utworzenia obwodów głosowania na polskich statkach morskich w wyborach do Sejmu Rzeczypospolitej Polskiej i do Senatu Rzeczypospolitej Polskiej (Dz. U. 2015, poz. 1650).

Rozporządzenie Ministra Gospodarki Morskiej i Żeglugi Śródlądowej z dnia 5 lipca 2016 r. w sprawie listy załogi statku (Dz. U. 2016, poz. 1016).

\section{Postanowienia}

Postanowienie Marszałka Sejmu Rzeczypospolitej Polskiej z dnia 4 lutego 2015 r. o zarządzeniu wyborów Prezydenta Rzeczypospolitej Polskiej (Dz. U. 2015, poz. 188).

Postanowienie Prezydenta Rzeczypospolitej Polskiej z dnia 17 czerwca 2015 r. o zarządzeniu ogólnokrajowego referendum (Dz. U. 2015, poz. 852).

Postanowienie Prezydenta Rzeczypospolitej Polskiej z dnia 17 lipca 2015 r. w sprawie zarządzenia wyborów do Sejmu Rzeczypospolitej Polskiej i do Senatu Rzeczypospolitej Polskiej (Dz. U. 2015, poz. 1017).

\section{Uchwaly}

Uchwała Państwowej Komisji Wyborczej z dnia 16 maja 2011 r. w sprawie trybu i terminu powoływania obwodowych komisji wyborczych w obwodach głosowania utworzonych na polskich statkach morskich (M. P. 2011, nr 44, poz. 476).

Uchwała Państwowej Komisji Wyborczej z dnia 3 lutego 2014 r. w sprawie wzorów kart do głosowania w wyborach do Parlamentu Europejskiego dla obwodów głosowania utworzonych za granicą i na polskich statkach morskich (M. P. 2014, poz. 139).

Uchwała Państwowej Komisji Wyborczej z dnia 10 lutego 2014 r. w sprawie sposobu sporządzania i przekazania kart do głosowania dla obwodów głosowania utworzonych na polskich statkach morskich w wyborach do Parlamentu Europejskiego w 2014 r. (M. P. 2014, poz. 179).

Uchwała Państwowej Komisji Wyborczej z dnia 17 lutego 2014 r. w sprawie zasad i trybu przekazywania okręgowej komisji wyborczej właściwej dla siedziby armatora wyników głosowania i protokołów głosowania $\mathrm{z}$ obwodów utworzonych na polskich statkach morskich w wyborach do Parlamentu Europejskiego (M. P. 2014, poz. 181).

Uchwała Państwowej Komisji Wyborczej z dnia 24 marca 2014 r. w sprawie wytycznych dla obwodowych komisji wyborczych dotyczących zadań i trybu przygotowania oraz przeprowadzenia głosowania w obwodach głosowania utworzonych za granicą i na polskich statkach morskich w wyborach do Parlamentu Europejskiego, zarządzonych na dzień 25 maja 2014 r. (M. P. 2014, poz. 257). 
Uchwała Państwowej Komisji Wyborczej z dnia 4 lutego 2015 r. w sprawie wzorów kart do głosowania dla obwodów głosowania utworzonych za granicą i na polskich statkach morskich w wyborach Prezydenta Rzeczypospolitej Polskiej w 2015 r. (M. P. 2015, poz. 153).

Uchwała Państwowej Komisji Wyborczej z dnia 23 lutego 2015 r. w sprawie sposobu sporządzania i przekazania kart do głosowania dla obwodów głosowania utworzonych na polskich statkach morskich w wyborach Prezydenta Rzeczypospolitej Polskiej w 2015 r. (M. P. 2015, poz. 252).

Uchwała Państwowej Komisji Wyborczej z dnia 14 kwietnia 2015 r. w sprawie zasad i trybu przekazywania okręgowej komisji wyborczej właściwej dla siedziby armatora wyników głosowania i protokołów głosowania z obwodów utworzonych na polskich statkach morskich w wyborach Prezydenta Rzeczypospolitej Polskiej, zarządzonych na dzień 10 maja 2015 r. (M. P. 2015, poz. 346).

Uchwała Państwowej Komisji Wyborczej z dnia 22 czerwca 2015 r. w sprawie wzorów karty do głosowania oraz nakładki na kartę do głosowania sporządzonej w alfabecie Braille’a w referendum ogólnokrajowym zarządzonym na dzień 6 września 2015 r. (M. P. 2015, poz. 572).

Uchwała Państwowej Komisji Wyborczej z dnia 6 lipca 2015 r. w sprawie trybu i terminu powoływania obwodowych komisji do spraw referendum w obwodach głosowania utworzonych na polskich statkach morskich w referendum ogólnokrajowym (M. P. 2015, poz. 632).

Uchwała Państwowej Komisji Wyborczej z dnia 20 lipca 2015 r. w sprawie zasad i trybu przekazywania komisarzowi wyborczemu właściwemu dla siedziby armatora wyników głosowania i protokołów głosowania $\mathrm{z}$ obwodów utworzonych na polskich statkach morskich w referendum ogólnokrajowym zarządzonym na dzień 6 września 2015 r. (M. P. 2015, poz. 664).

Uchwała Państwowej Komisji Wyborczej z dnia 27 lipca 2015 r. w sprawie wytycznych dla obwodowych komisji do spraw referendum, dotyczących zadań i trybu przygotowania oraz przeprowadzenia głosowania w obwodach głosowania utworzonych za granicą i na polskich statkach morskich w referendum ogólnokrajowym zarządzonym na dzień 6 września $2015 \mathrm{r}$. (M. P. 2015, poz. 749).

Uchwała Państwowej Komisji Wyborczej z dnia 3 sierpnia 2015 r. w sprawie zasad drukowania i przekazania kart do głosowania dla obwodów głosowania utworzonych na polskich statkach morskich w referendum ogólnokrajowym zarządzonym na dzień 6 września 2015 r. (M. P. 2015, poz. 709).

Uchwała Państwowej Komisji Wyborczej z dnia 3 września 2015 r. w sprawie wzorów kart do głosowania w wyborach do Sejmu Rzeczypospolitej Polskiej i do Senatu Rzeczypospolitej Polskiej dla obwodów głosowania utworzonych za granicą i na polskich statkach morskich (M. P. 2015, poz. 846).

Uchwała Państwowej Komisji Wyborczej z dnia 16 września 2015 r. w sprawie sposobu sporządzania i przekazania kart do głosowania dla obwodów głosowania utworzonych na polskich statkach morskich w wyborach do Sejmu Rzeczypospolitej Polskiej i do Senatu Rzeczypospolitej Polskiej, zarządzonych na dzień 25 października 2015 r. (M. P. 2015, poz. 914).

Uchwała Państwowej Komisji Wyborczej z dnia 16 września 2015 r. w sprawie trybu i terminu powoływania obwodowych komisji wyborczych w obwodach głosowania utworzonych na polskich statkach morskich (M. P. 2015, poz. 926).

Uchwała Państwowej Komisji Wyborczej z dnia 16 września 2015 r. w sprawie zasad i trybu przekazywania okręgowej komisji wyborczej właściwej dla siedziby armatora wyników głosowania i protokołów głosowania z obwodów utworzonych na polskich statkach morskich w wyborach do Sejmu Rzeczypospolitej Polskiej i do Senatu Rzeczypospolitej Polskiej, zarządzonych na dzień 25 października 2015 r. (M. P. 2015, poz. 928). 
Uchwała Państwowej Komisji Wyborczej z dnia 5 października 2015 r. w sprawie wytycznych dla obwodowych komisji wyborczych dotyczących zadań i trybu przygotowania oraz przeprowadzenia głosowania w obwodach głosowania utworzonych za granicą i na polskich statkach morskich w wyborach do Sejmu Rzeczypospolitej Polskiej i do Senatu Rzeczypospolitej Polskiej, zarządzonych na dzień 25 października 2015 r. (M. P. 2015, poz. 1020).

\section{Inne}

Decyzja nr 242/MON Ministra Obrony Narodowej z dnia 21 czerwca 2011 r. w sprawie wprowadzenia do użytku Regulaminu Służby na Okrętach Marynarki Wojennej (Dz. Urz. MOPN 2011, nr 13, poz. 191).

\section{KORESPONDENCJA URZĘDOWA}

Pismo prezydenta Rzeczypospolitej Polskiej Bronisława Komorowskiego do marszałka Sejmu Rzeczypospolitej Polskiej Radosława Sikorskiego z dnia 8 stycznia 2015 r.

Pismo prezesa zarządu, dyrektora naczelnego LOTOS Petrobaltic S.A. mgr. inż. Zbigniewa Paszkowicza do podsekretarza stanu w Ministerstwie Infrastruktury i Rozwoju z dnia 9 stycznia $2015 \mathrm{r}$.

Pismo przewodniczącego Państwowej Komisji Wyborczej Wojciecha Hermelińskiego do podsekretarza stanu w Ministerstwie Infrastruktury i Rozwoju dr hab. Doroty Pyć z dnia 19 stycznia 2015 r., ZPOW-430-1/15.

Pismo podsekretarza stanu w Ministerstwie Infrastruktury i Rozwoju dr hab. Doroty Pyć do przewodniczącego Komisji Nadzwyczajnej do Spraw Zmian w Kodyfikacjach Sejmu Rzeczypospolitej Polskiej Witolda Pahla z dnia 18 lutego 2015 r., DTM-VI-0210-2-AM/15 NK:44807/15.

Pismo przewodniczącego Państwowej Komisji Wyborczej Wojciecha Hermelińskiego do podsekretarza stanu w Ministerstwie Infrastruktury i Rozwoju dr hab. Doroty Pyć z dnia 26 lutego 2015 r., ZPOW-430-1/15.

Pismo przewodniczącego Państwowej Komisji Wyborczej Wojciecha Hermelińskiego do podsekretarza stanu w Ministerstwie Infrastruktury i Rozwoju dr hab. Doroty Pyć z dnia 3 marca 2015 r., ZPOW-600-2/15.

Pismo prezesa zarządu, dyrektora naczelnego LOTOS Petrobaltic S.A. mgr. inż. Zbigniewa Paszkowicza do ministra infrastruktury i rozwoju mgr Marii Wasiak z dnia 31 marca 2015 r., $\mathrm{NK} / \mathrm{w} / 187 / 2015$.

Pismo zastępcy przewodniczącego Państwowej Komisji Wyborczej Wiesława Kozielewicza do podsekretarza stanu w Ministerstwie Infrastruktury i Rozwoju dr hab. Doroty Pyć z dnia 14 kwietnia 2015 r., ZPOW-600-2/15.

Pismo kierownika Zespołu Armatorskiego Instytutu Oceanologii Polskiej Akademii Nauk dr. inż. Andrzeja Kadłubickiego do Ministerstwa Infrastruktury i Rozwoju z dnia 22 czerwca 2015 r., IO/TA/1111/15.

Pismo Ministra Administracji i Cyfryzacji (z up. sekretarz stanu mgr Stanisław Huskowski) do ministra infrastruktury i rozwoju mgr Marii Wasiak, ministra spraw wewnętrznych mgr Teresy Piotrowskiej, ministra spraw zagranicznych mgr. Grzegorza Schetyny, prezesa Rządowego Centrum Legislacji mgr. Macieja Berka i generalnego inspektora ochrony danych osobowych dr Edyty Bielak-Jomaa z dnia 14 lipca 2015 r., DP-WL.0211.50.2015.

Pismo prezesa zarządu, dyrektora naczelnego LOTOS Petrobaltic S.A. mgr. inż. Zbigniewa Paszkowicza do ministra infrastruktury i rozwoju mgr Marii Wasiak z dnia 20 lipca 2015 r., $\mathrm{NK} / \mathrm{w} / 550 / 2015$. 
Pismo zastępcy dyrektora do spraw naukowych Instytutu Oceanologii Polskiej Akademii Nauk prof. nadzw. IO PAN dr hab. Kseni Pazdro do ministra infrastruktury i rozwoju mgr Marii Wasiak z dnia 22 lipca 2015 r., IO/TA/1295/2015.

Pismo kierownika Działu Armatorskiego Akademii Morskiej w Gdyni mgr Katarzyny Majewskiej do ministra infrastruktury i rozwoju mgr Marii Wasiak z dnia 30 lipca 2015 r.

Pismo zastępcy przewodniczącego Państwowej Komisji Wyborczej Wiesława Kozielewicza do podsekretarza stanu w Ministerstwie Infrastruktury i Rozwoju dr hab. Doroty Pyć z dnia 12 sierpnia 2015 r., ZPOW-800-9/15.

Pismo dyrektora Morskiego Instytutu Rybackiego - Państwowego Instytutu Badawczego dr. Emila Kuzebskiego do Ministerstwa Infrastruktury i Rozwoju z dnia 8 września 2015 r., DO/2727/52/2015.

Pismo dyrektora, pełnomocnika armatora The Sail Training Association Poland Marka Klebana do Ministerstwa Infrastruktury i Rozwoju z dnia 14 września 2015 r., 109/2015.

Pismo kierownika Biura Zarządzania Zasobami Ludzkimi LOTOS Petrobaltic S.A. mgr Katarzyny Sowy do ministra infrastruktury i rozwoju mgr Marii Wasiak z dnia 15 września 2015 r., $\mathrm{NK} / \mathrm{w} / 753 / 2015$.

Pismo przewodniczącego Państwowej Komisji Wyborczej Wojciecha Hermelińskiego do podsekretarza stanu w Ministerstwie Infrastruktury i Rozwoju dr hab. Doroty Pyć z dnia 7 października 2015 r., ZPOW-500-3/15.

Pismo zastępcy przewodniczącego Państwowej Komisji Wyborczej Wiesława Kozielewicza do podsekretarza stanu w Ministerstwie Infrastruktury i Rozwoju dr hab. Doroty Pyć z dnia 20 października 2015 r., ZPOW-430-1/15.

Pismo Ministra Infrastruktury i Rozwoju (z up. podsekretarz stanu dr hab. Dorota Pyć) do przewodniczącego Państwowej Komisji Wyborczej Wojciecha Hermelińskiego z dnia 5 listopada 2015 r., DTM.VI.0210.8.8.2015.AM NK:303232/15.

Pismo sekretarza Państwowej Komisji Wyborczej Beaty Tokaj do podsekretarza stanu w Ministerstwie Infrastruktury i Rozwoju z dnia 16 listopada 2015 r., ZPOW-430-1/15.

Pismo Ministra Gospodarki Morskiej i Żeglugi Śródlądowej (wz. podsekretarz stanu dr Krzysztof Kozłowski) do przewodniczącego Państwowej Komisji Wyborczej Wojciecha Hermelińskiego z dnia 4 grudnia 2015 r., DTM.VI.0210.8.13.2015.AM NK:329777/15.

Pismo sekretarza Państwowej Komisji Wyborczej Beaty Tokaj do podsekretarza stanu w Ministerstwie Gospodarki Morskiej i Żeglugi Śródlądowej dr. Krzysztofa Kozłowskiego z dnia 11 grudnia 2015 r., ZPOW-430-1/15.

Pismo podsekretarza stanu w Ministerstwie Gospodarki Morskiej i Żeglugi Śródlądowej Pawła Brzezickiego do przewodniczącego Państwowej Komisji Wyborczej Wojciecha Hermelińskiego z dnia 30 grudnia 2015 r., DTM.VI.0210.8.15.AM NK:351060/15.

Pismo sekretarza Państwowej Komisji Wyborczej Beaty Tokaj do podsekretarza stanu w Ministerstwie Gospodarki Morskiej i Żeglugi Śródlądowej Pawła Brzezickiego z dnia 7 stycznia 2016 r., ZPOW-430-1/15.

Pismo podsekretarza stanu w Ministerstwie Gospodarki Morskiej i Żeglugi Śródlądowej Pawła Brzezickiego do przewodniczącego Państwowej Komisji Wyborczej Wojciecha Hermelińskiego z dnia 15 stycznia 2016 r., DTM.VI.0210.8.16.2015.AM NK:398/2016.

Pismo sekretarza Państwowej Komisji Wyborczej Beaty Tokaj do podsekretarza stanu w Ministerstwie Gospodarki Morskiej i Żeglugi Śródlądowej Pawła Brzezickiego z dnia 22 stycznia 2016 r. (w oryginale błędnie 2015), ZPOW-430-1/15.

Pismo szefa Krajowego Biura Wyborczego Beaty Tokaj do dr. Macieja Kijowskiego z dnia 28 grudnia 2016 r., ZPOW-066-254/16. 
Pismo sekretarza Państwowej Komisji Wyborczej Beaty Tokaj do podsekretarza stanu w Ministerstwie Gospodarki Morskiej i Żeglugi Śródlądowej Pawła Brzezickiego z dnia 3 stycznia 2017 r., ZPOW-430-1/15/16.

Pismo Ministra Cyfryzacji (z up. sekretarz stanu Marek Zagórski) do podsekretarza stanu w Ministerstwie Gospodarki Morskiej i Żeglugi Śródlądowej Pawła Brzezickiego z dnia 5 stycznia 2017 r., DP-WLII.0210.811.2016.

Pismo dyrektora Departamentu Prawnego Ministerstwa Gospodarki Morskiej i Żeglugi Śródlądowej dr. Bartosza Szczurowskiego do dyrektora Departamentu Prawa Gospodarczego Rządowego Centrum Legislacji Moniki Salamończyk z dnia 9 lutego 2017 r., DP.022.662.2016. BS.

Pismo dyrektora Departamentu Prawa Pracy, Rodziny i Infrastruktury Rządowego Centrum Legislacji Agnieszki Juszczyk do dyrektora Departamentu Prawnego Ministerstwa Gospodarki Morskiej i Żeglugi Śródlądowej dr. Bartosza Szczurowskiego z dnia 20 lutego 2017 r., RCL. DPŚI.555.230/2015.

\section{Inne źródla drukowane}

Druki sejmowe.

Krajowe Biuro Wyborcze, Dokumentacja niearchiwalna.

Sejm RP. VII kadencja. Pełny zapis przebiegu posiedzenia Komisji Nadzwyczajnej do spraw zmian w kodyfikacjach (nr 91) z dnia 22 kwietnia 2015 r.

Sprawozdania Stenograficzne z posiedzeń Sejmu Rzeczypospolitej Polskiej.

Sprawozdanie Podkomisji stałej do spraw nowelizacji Kodeksu wyborczego z dnia 10 kwietnia $2015 \mathrm{r}$.

\section{Źródła internetowe}

wpolityce.pl/polityka/243941-marynarze-bez-prawa-do-glosowania-wybory-możliwe-tylko-na-statkach-z-polska-bandera.

www.fryderykchopin.pl/regulamin-pokladowy.t22/.

www.pogoria.pl/pl/content/regulamin-sts-pogoria.

\section{STRESZCZENIE}

Tematem artykułu są wybory do sejmu i senatu, wybory prezydenta i wybory do Parlamentu Europejskiego oraz referendum ogólnokrajowe odbywane na polskich statkach morskich (w rozumieniu Kodeksu wyborczego). Szczególna uwaga zwrócona jest na specyficzne kompetencje kapitana statku. Opierając się na przytoczonych przepisach i ich praktycznym zastosowaniu autor komentuje (także krytycznie) obecne rozwiązania i wysuwa propozycje ich nowelizacji.

Słowa kluczowe: wybory, referendum, statek morski, kapitan 
THE ELECTIONS AND THE NATIONWIDE REFERENDUM ON THE POLISH SEAGOING VESSELS. FACTS, CONCLUSIONS, OBSERVATIONS (summary)

The article deals with the elections to the Sejm and the Senate, the presidential elections, the elections to the European Parliament as well as the nationwide referendum that are held on the Polish sea-going vessels (in the meaning of the Electoral Code). The author pays special attention to the specific competences of the shipmaster. Basing on quoted rules and their practical application the author comments (also critically) the present regulations and makes proposals of their amendment.

Keywords: elections, referendum, sea-going vessel, shipmaster. 